\title{
An indicator for organic matter dynamics in temperate agricultural soils
}

\author{
${\text { Bas van } \text { Wesemael }^{\mathrm{a}, *} \text {, Caroline Chartin }}^{\mathrm{a}}$, Martin Wiesmeier ${ }^{\mathrm{b}, \mathrm{c}}$, Margit von Lützow ${ }^{\mathrm{b}}$, \\ Eleanor Hobley ${ }^{\mathrm{b}}$, Monique Carnol ${ }^{\mathrm{d}}$, Inken Krüger ${ }^{\mathrm{d}}$, Morgane Campion ${ }^{\mathrm{e}}$, Christian Roisin ${ }^{\mathrm{e}}$, \\ Sylvain Hennart ${ }^{\mathrm{e}}$, Ingrid Kögel-Knabner ${ }^{\mathrm{b}, \mathrm{f}}$ \\ ${ }^{a}$ Georges Lemaître Centre for Earth and Climate Research, Earth and Life Institute, Université Catholique de Louvain, 1348 Louvain-la-Neuve, Belgium \\ ${ }^{\mathrm{b}}$ Chair of Soil Sciences, TUM School of Life Sciences Weihenstephan, Technical University of Munich, Freising, Germany \\ ${ }^{\mathrm{c}}$ Bavarian State Research Center for Agriculture, Institute for Organic Farming, Soil and Resource Management, Freising, Germany \\ ${ }^{\mathrm{d}}$ Laboratory of Plant and Microbial Ecology, InBioS, University of Liège, 4000 Liège, Belgium \\ ${ }^{\mathrm{e}}$ Agriculture and Natural environment department, Walloon Agricultural Research Centre, 5030 Gembloux, Belgium \\ ${ }^{\mathrm{f}}$ Institute for Advanced Study, Technical University of Munich, Garching, Germany
}

\section{A R T I C L E I N F O}

\section{Keywords:}

Soil organic matter fractionation

Indicator

Soil organic carbon dynamics

Long-term trials

Organic matter management

\begin{abstract}
A B S T R A C T
The heterogeneity of soil organic matter (SOM) and the small changes in soil organic carbon (SOC) compared to large total SOC stocks hinder a robust estimation of SOC turnover, in particular for more stable SOC. We developed a simple fractionation protocol for agricultural topsoils and tested it extensively on a range of soils in southern Belgium, including farmed soils, soils from long-term field trials, and paired sites after recent conversion to conservation farming. Our simple fractionation involves shaking the soil, wet sieving over $20 \mu \mathrm{m}$ and analysing the SOC concentration in the soil as well as in the fine fraction $(<20 \mu \mathrm{m})$. Eight biological indicators measured in an earlier study across the same monitoring network for the $0-10 \mathrm{~cm}$ topsoil were analysed in a conditional inference forest model in order to investigate the factors influencing the SOC fractions. Soil microbial biomass $\mathrm{N}$ explained the largest proportion of variation in both fractions. The fine fraction was also associated with factors explaining the regional trend in SOC distribution such as farmyard manure input, precipitation, land use and flow length. The variation in SOC content between treatments both in long-term trials and in farmers' fields converted to conservation management was mainly attributed to changes within the coarse fraction. Thus, this fraction proves to be sensitive to management changes, although care should be taken to sample deep enough to represent the former plough layer inherited from the conventional tillage practice. Furthermore, the ratio between the coarse and the fine fraction showed a linear relationship $\left(r^{2}=0.66\right)$ with the relative changes in SOC concentration over the last ten years. These fractions derived from a simple analytical approach are thus useful as an indicator for changes in SOC concentration. In analogy to biological indicators such as the soil microbial biomass $\mathrm{C}$, the relationship between the fractions and relative changes in SOC concentration are likely to depend on climate conditions. Our methodology provides an indicator for use in routine analysis of agricultural topsoils, which is capable of predicting the effects of management practices on SOC concentrations in the short to mid-term (5-10 years).
\end{abstract}

\section{Introduction}

Agricultural soils have lost a portion of their organic matter through an imbalance between reduced $\mathrm{C}$ input, e.g. due to export of crops, and enhanced $\mathrm{C}$ output e.g. due to decomposition after disturbance by ploughing. Preserving and where possible enhancing SOM storage is one of the aims of conservation agriculture, resulting in improved soil functions such as enhanced water retention and nutrient cycling, in particular for soils with low SOM contents. Additionally, agricultural soils are considered to have the potential to mitigate climate change by C sequestration globally (Minasny et al., 2017) and thus compensate at least a part of the fossil fuel emissions and at the same time restore soil fertility (e.g. the ' 4 per mille' initiative launched by France at the COP 21 https://www.4p1000.org/).

Although fertilizers largely compensate the loss of soil fertility in temperate agricultural systems, less attention is paid to the compensation of SOM decreases, as these occur slowly and their effect on soil fertility, crop yields, and climate mitigation is not generally quantified

\footnotetext{
* Corresponding author at: Earth and Life Institute, Université catholique de Louvain, Place Louis Pasteur 3 bte L4.03.08, B 1348 Louvain-la-Neuve, Belgium.

E-mail address: bas.vanwesemael@uclouvain.be (B. van Wesemael).
} 
(Kibblewhite et al., 2016). Conservation agriculture aims at reducing soil disturbance by ploughing, increasing input of organic amendments, diversifying the rotation and lengthening the period during which a crop is grown. These measures have a beneficial effect on the key indicators for soil health, be it biological properties (e.g. microbial biomass $\mathrm{C}$, mean organic matter residence time, earthworms, soil enzymes, nematodes and pathogens, mycorrhizal fungi, soil respiration) or ecological functions (e.g. nutrient cycling, hydrological budget, energy budget, erosion, biodiversity, landscape processes; Lal, 2016).

Unfortunately, biological indicators and SOC content analysis are limited in their ability to detect changes at relevant temporal scales. Powlson et al. (1987) and Anderson and Domsch (1989) already demonstrated that microbial biomass $\mathrm{C}$ is sensitive to increases in straw incorporation in agricultural soils and proposed a threshold of $2.9 \%$ for the ratio of microbial C to SOC below which SOC decreases over time. However, the analysis of microbial $\mathrm{C}$ requires at least a day of fumigation, results are not directly related to mineralization rate (Kemmitt et al., 2008) and subject to seasonal variation (cv 29\%; Krüger et al., 2018). Moreover, the heterogeneity of SOM is such that it is difficult to detect small changes in input against a large background of SOM that built over centuries (Powlson et al., 1987).

Routine soil analysis for fertilization recommendations is common practice for both croplands and grasslands and provides information on a limited number of soil parameters such as N, P, pH and SOM, with around 20,000 fields analysed each year in the Walloon Region (Genot et al., 2011). Recently, VisNIR spectroscopy is increasingly used in order to replace SOC analysis and estimate the clay content and CEC, while promising calibrations for soil fractions have been published by Jaconi et al. (2019). An additional indicator for the risk of SOM decline to be included in the soil fertility advice would enable farmers to engage in SOM management and eventually contribute to the challenges of e.g. the 4 per mille initiative. The constraints of such an indicator are obviously the sampling depth used for fertility advice (i.e. $0-20 \mathrm{~cm}$ in cropland and $0-10 \mathrm{~cm}$ in grassland), labour requirement and the insertion in a routine soil analysis chain. In this context techniques such as sonication and flotation in heavy liquids are rather complex and should be avoided (Poeplau and Don, 2014).

Different protocols were developed to separate fractions of SOC ranging from $\mathrm{C}$ stabilized by organo-mineral complexes to partly decomposed organic residues (von Lützow et al., 2007; Poeplau et al., 2018). Some of these fractions are in fact related to stable organic matter and reflect long-term (10-100 years) C storage. Liang et al. (2017) proposed a conceptual model reconciling decomposition and occlusion of $\mathrm{OM}$ and stressed the importance of stabilization with mineral surfaces in the fine fraction. The stabilization of organic matter by the fine silt and clay fraction $(<20 \mu \mathrm{m})$ has opened the debate on a maximum content of stable $\mathrm{C}$ for a given soil texture (Hassink, 1997; Six et al., 2002; Feng et al., 2013). Spatial models could be developed in order to estimate $\mathrm{C}$ sequestration potentials for this stable fraction (Angers et al., 2011; Wiesmeier et al., 2014). Chronosequences after land abandonment have shown that the changes in this stabilized $\mathrm{C}$ fraction over time are slow ( $>60$ years; Trigalet et al., 2016). Stewart et al (2008) demonstrated that three conceptual pools based on i) stabilization through chemical association with silt and clay particles, ii) physical protection within micro aggregates and iii) biological complexity of the organic compounds can be isolated through a three step fractionation using dispersion and wet sieving, flotation in heavy liquids and acid hydrolysis.

Our hypothesis is that through a wet sieving procedure after disaggregation we can derive two fractions corresponding to two of the three conceptual pools i.e. stabilization with silt and clay particles and physical protection within (micro) aggregates. Stewart et al (2008) stress that these fractions should be separated by dispersion and by wet sieving, as sonication will destroy the smaller (micro) aggregates. The fraction smaller than $20 \mu \mathrm{m}$ contains free silt and clay as well as small micro aggregates. The organic matter in this fraction consists of stabilized organo-mineral complexes (Lal, 2016; Liang et al., 2017; Totsche et al., 2018) and the amount of $\mathrm{C}$ is limited by the sorption capacity of the soil, thus leading to C saturation (Hassink, 1997; Six et al., 2002; Feng et al., 2013). The fraction larger than $20 \mu \mathrm{m}$ is more heterogeneous, consisting of micro aggregates, small macro aggregates (that withstand shaking), organic matter associated with coarse silt and sand, and particulate organic matter (POM). In agricultural soils, the POM fraction is rather limited at less than $10 \%$ of the total SOC (Wiesmeier et al., 2014). Given the hierarchical organization of aggregates (Tisdall and Oades, 1982), the macro aggregates also contain micro aggregates that reflect stabilized fraction (Six et al., 2002). The binding and storage capacity of coarse particles for $\mathrm{C}$ is limited, but the $\mathrm{C}$ stored in sand particles has been shown to be highly sensitive to landuse change (Leifeld and Kögel-Knabner, 2005)

We expected that a fraction $>20-50 \mu \mathrm{m}$ would respond rather quickly to increases in return of crop residues to the soil and reduced soil disturbance. After all, these are the main aims of conservation agriculture. If such a management regime persists, an abundant coarse fraction that is decomposed rather quickly will feed the soil biota and gradually part of the $C$ in the coarse fraction would be stabilized in the fine fraction. Thus, a sensitive indicator can be developed to inform farmers on the effects of management changes on SOM.

The aim of this paper was thus to test the capacity of a simple organic matter fractionation scheme as an indicator for the effects of management on the short to mid-term dynamics of organic matter (5-10 years) in agricultural soils. To do this we characterized SOC fractions and investigated the drivers (topography, soil, climate, land use, biological indicators) for variation in SOC fractions from sites within a soil monitoring network with additional sites from long-term trials and paired plots in farmers' fields. The biological indicators (respiration potential, microbial biomass carbon, microbial $\mathrm{C} / \mathrm{N}$ ratio, net nitrogen mineralisation, metabolic potential of soil bacteria, earthworm abundance, microbial quotient, and metabolic quotient) were analysed on the same sampling points in order to develop a reference system (Krüger et al., 2018). We used a conditional inference forest analysis for determining the factors and ranking their importance as drivers for the SOC fractions (Hobley et al., 2015). Then we investigated the sensitivity of fractions to treatments in controlled conditions (long-term trials, paired plots), and finally selected the most effective indicator based on the fractions. Using this approach we were able to i) determine the drivers of and relations to soil functions for the derived $\mathrm{C}$ fractions, ii) demonstrate the sensitivity of the $\mathrm{C}$ fractions to the effects of management, and iii) propose an indicator for soil $\mathrm{C}$ status based on these $\mathrm{C}$ fractions.

\section{Materials and methods}

\subsection{Study area}

The data was collected in Wallonia, which is the southern part of Belgium and covers an area of c. $16,800 \mathrm{~km}^{2}$. This region has been selected for a number of studies on the spatial distribution of SOC in agricultural soils, such as the evolution of SOC stocks over the last fifty years (Goidts and van Wesemael, 2007) and the mapping of SOC stocks (Chartin et al., 2017). Detailed information on the study area can be found in these papers. Briefly, the area has a maritime climate in the northwest (mean annual precipitation $(\mathrm{P})=700 \mathrm{~mm}$ and mean annual temperature $=10-11^{\circ} \mathrm{C}$ ) and a more continental climate in the southeast $\left(\mathrm{P}=1060-1200 \mathrm{~mm}\right.$ and mean annual temperature is $\left.8-9^{\circ} \mathrm{C}\right)$. The northern part comprises a plateau at around $100-120 \mathrm{~m}$ above sea level (asl) consisting of Quaternary niveo eolian loess sediment of silt to silt loam texture with a Haplic Luvisols (IUSS Working Group WRB., 2015). The soils are fertile and dominated by cropland systems in which wheat, barley and sugar beet are grown in rotation. The southeastern part consists of high plateau and valleys of the Ardennes (250-690 m asl) and has a substratum of Devonian rocks. Soils are thinner and often 


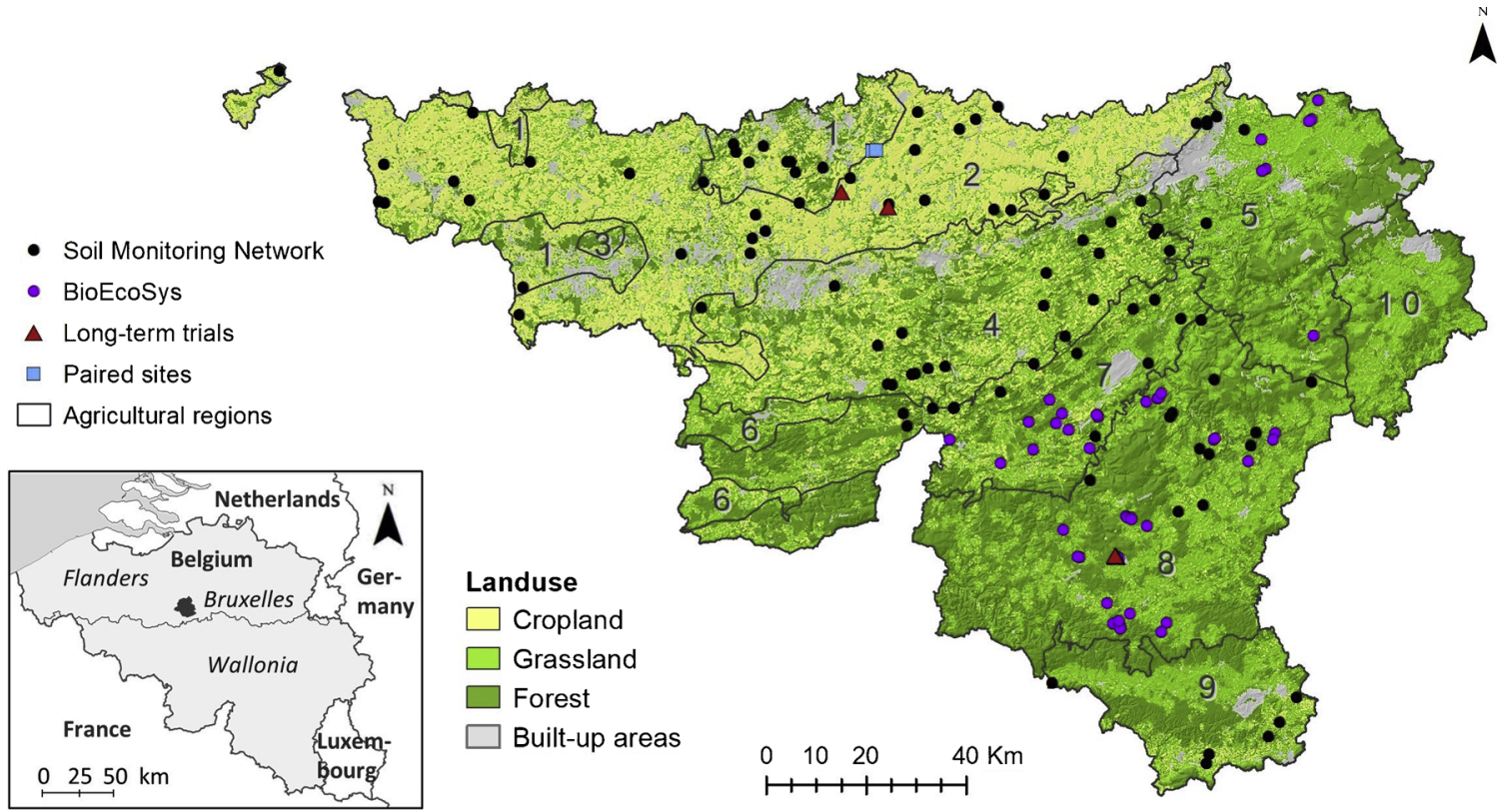

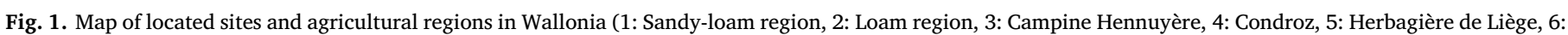
Herbagère Fagnes, 7: Famenne, 8: Ardenne, 9: Jura and 10: Haute Ardenne.

stony, classified as Dystric Cambisols with Fluvisols in the valley bottoms. The land use in the southern part is dominated by extensive grassland systems for cattle breeding and forests. Within Wallonia ten agricultural regions are distinguished with, to a large extent, similar soils, topography and cropping practices (Fig. 1).

\subsection{Soil monitoring network}

Firstly, 434 profiles were sampled in two campaigns (August 2004 August 2005 and October 2006 - May 2007) from 15 units with homogeneous land use, belonging to the same agricultural region and with similar soil texture, drainage and stoniness (referred to as LSU, or landscape unit; Goidts et al., 2009). The sampling was extended from March 2014 to June 2014, covering another 30 LSU's with 158 sampling sites (Chartin et al., 2017). These 592 sites were marked with an electromagnetic ball marker $(3 \mathrm{M})$ buried at $1 \mathrm{~m}$ below surface in order to allow a precise relocation.

In April and May 2015, we re-sampled 30 sites in cropland and 30 sites in grassland selected among the 434 profiles originally sampled by Goidts et al. (2009). The sites were selected from ten LSU's using a latin hypercube for site selection (Minasny and McBratney, 2006), constrained by geographical coordinates and concentration of fine silt and clay from the maps produced by Chartin et al. (2017). Furthermore, we used 37 sites selected among the 158 additional sites mentioned above in order to increase the variability in environmental conditions.

\subsection{Long-term trials}

The long-term trials in Long Tours $\left(50^{\circ} 33^{\prime} \mathrm{N}, 4^{\circ} 43^{\prime} \mathrm{E}\right)$ started in 1959 and consist of different treatments with organic amendments. The site is described in detail by Buysse et al. (2013) and Trigalet et al. (2014). The field is in a flat landscape position within the loam region and the soils are tilled using a mouldboard plough until $23-27 \mathrm{~cm}$ (Fig. 1). Additionally, the cereal stubbles are ploughed in with a spring tine cultivator $(0-10 \mathrm{~cm})$ and the seedbed is prepared with a disk harrow $(5-8 \mathrm{~cm})$. Initially, there was a four-year rotation of sugar beet, winter wheat, winter barley and horse bean, but it changed to a threeyear rotation (sugar beet, winter cereal, winter cereal) in 1975. Two treatments were sampled: the control, where aboveground crop residues were exported and no organic fertilizer was used (RE treatment), and the residue return treatment ( $R R$ treatment), where residues were left in the field and a cover crop was grown in the winter preceding the sugar beet. The two treatments received the same amount of mineral fertilizer. Four composite samples in each treatment were collected in April 2016.

The long-term trial in Gentinnes $\left(50^{\circ} 35^{\prime} \mathrm{N} 4^{\circ} 35^{\prime} \mathrm{E}\right)$ in the loam region dates from 2008 and encompasses three tillage treatments: i) conventional tillage with a mouldboard plough until $27 \mathrm{~cm}$ depth (CT), ii) deep de-compaction with a heavy tine cultivator until $30 \mathrm{~cm}$ (DT) every second year before the seeding of the sugar beet and a spring tine cultivator until $10 \mathrm{~cm}$ during the other year, and iii) reduced tillage with a spring tine cultivator until $10 \mathrm{~cm}$ depth (RT; Fig. 1). The seedbed for all treatments is prepared with a disk harrow to a depth of 5-8 cm. There is a two-year rotation with sugar beet and winter cereals. A cover crop is sown after tillage and left to decompose at the surface. The cereal straw is chopped and mixed in the topsoil (Jonard et al., 2013). Four composite samples in each treatment were collected in June, 2017.

The long-term trial in Libramont $\left(49^{\circ} 55^{\prime} \mathrm{N} 5^{\circ} 21^{\prime} \mathrm{E}\right)$ is located in the Ardenne region (Fig. 1). The site was established in 1996 and converted to organic agriculture in 2010. The grassland consists of perennial rye grass and white clover and is grazed by cattle in rotation with on average five large livestock equivalents. Stocking density for each grazing was adapted according to available biomass and excess grass production in spring was mown for silage. There are four treatments: 1) composted farm yard manure $\left(10 \mathrm{Mg}\right.$ ha $\left.^{-1} \mathrm{y}^{-1}\right)$ until 2010 and no amendments or fertilizer afterwards, 2) mineral fertilizer until 2010 and no amendments or mineral fertilizer afterwards, 3) composted manure (10 Mg ha $\left.\mathrm{y}^{-1}\right)$ and 4) mineral fertilizer until 2010 and composted manure from 2010 onwards $\left(10 \mathrm{Mg} \mathrm{ha}^{-1} \mathrm{y}^{-1}\right)$. Each treatment consists of two replicates in each of which four composite samples were collected in March 2016.

\subsection{Paired sites}

Two paired sites were selected according to: i) availability of two comparable fields with one under conventional and the other under conservation agriculture, ii) the conventional site should be under winter wheat following a sugar beet crop. Four composite samples of each site were collected in June 2017. Furthermore, the fields under 
Table 1

Management practices for the Bioecosys grasslands.

\begin{tabular}{|c|c|c|c|c|c|c|c|}
\hline Management & Permanency & $\begin{array}{l}\text { Type of } \\
\text { management }\end{array}$ & Code & Ardenne & $\begin{array}{c}\mathbf{N}^{\mathbf{8}} \\
\text { Famenne }\end{array}$ & $\begin{array}{c}\text { Région } \\
\text { herbagière }\end{array}$ & $\begin{array}{c}\text { Management } \\
\text { Intensity }\end{array}$ \\
\hline \multirow{7}{*}{ 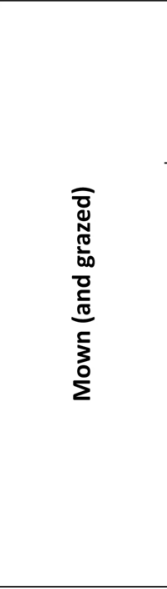 } & \multirow{2}{*}{ (Temporary } & $\begin{array}{l}\text { Intensive } \\
\text { conventional }^{1}\end{array}$ & Mt1 & 3 & - & - & intensive \\
\hline & & $\begin{array}{l}\text { Intensive } \\
\text { organic }^{2}\end{array}$ & $\mathrm{Mt2}$ & 3 & - & - & \\
\hline & \multirow{5}{*}{ Permanent } & $\begin{array}{l}\text { Intensive } \\
\text { conventional }^{1}\end{array}$ & Mp1 & 3 & 3 & 3 & \\
\hline & & $\begin{array}{l}\text { Intensive } \\
\text { organic }^{2}\end{array}$ & Mp5 & 3 & - & - & \\
\hline & & $\begin{array}{l}\text { Ist cut after } 15 \\
\text { June }^{1}\end{array}$ & Mp2 & 3 & - & - & \\
\hline & & $\begin{array}{l}\text { Natural } \\
\text { grassland }^{3}\end{array}$ & Mp3 & 3 & 3 & - & \\
\hline & & $\begin{array}{l}\text { Natural } \\
\text { grassland with } \\
\text { Late mowing }\end{array}$ & Mp4 & 4 & 4 & 4 & extensive \\
\hline \multirow{3}{*}{$\begin{array}{l}\text { D্ } \\
\text { ர் } \\
\text { i }\end{array}$} & \multirow{3}{*}{ Permanent } & $\begin{array}{l}\text { Continuous } \\
\text { intensive }\end{array}$ & Gp1 & 3 & - & - & intensive \\
\hline & & Rotating $^{6}$ & Gp2 & 3 & - & - & \\
\hline & & Natural grazing ${ }^{\top}$ & Gp3 & 4 & - & - & extensive \\
\hline
\end{tabular}

${ }^{1}$ 3-4 cuts with fertilizer and farmyard manure (FYM), suckler cows.

${ }^{2}$ 3-4 cuts with FYM only, suckler and dairy cows.

${ }^{3} 2-3$ cuts, no intervention between 1 January and 15 June, a single spreading of FYM between 15 June and 31 July, suckler cows.

${ }^{4} 1-2$ cuts, no intervention between 1 January and 15 June, no spreading of FYM, suckler cows.

5Continuous grazing between April and October/November, suckler cows.

${ }^{6}$ Grazing for 8-15 years, return to the field in 5-7 weeks, suckler cows.

${ }^{7}$ no intervention between 1 January and 15 June, no spreading of FYM, suckler cows.

${ }^{8}$ number of fields sampled.

conservation agriculture and the two treatments in the Long Tours (see Section 2.3) were sampled in April, June (after flowering of the wheat) and August (after harvest) 2016 in order to investigate the seasonal variability in SOM fractions.

\subsection{Bioecosys}

The Bioecosys network consists of 49 grassland fields within three agricultural regions: 32 in the Ardenne, 10 in the Famenne and 7 in the Région herbagière de Liège (Fig. 1). These grasslands have been managed at least for the last five years according to the local practices and contain temporary and permanent grasslands that are grazed and/or mown. They are arranged along a gradient from intensive to extensive management (Table 1). One composite sample in each field was collected in November 2016.

\subsection{Soil samples}

For the soil monitoring network, composite samples consisted of five points sampled by auger and located within a $4 \mathrm{~m}$ radius circle around the center referenced by the buried ball marker (Chartin et al., 2017; Krüger et al., 2018). Samples of all long-term trials, paired sites and Bioecosys were taken on the corners of a 10 by $10 \mathrm{~m}$ square laid out using a handheld GPS. On each corner a composite sample was collected. All samples for SOC concentration and C fractions were taken from 0 to $20 \mathrm{~cm}$ in cropland and 0 to $10 \mathrm{~cm}$ in grassland. These depth intervals are in agreement with the sampling for routine soil fertility analysis. For biological indicators only the $0-10 \mathrm{~cm}$ topsoil was sampled in both croplands and grasslands (Krüger et al., 2018). The biological indicators and the SOM fractions were never used in the same statistical test. Instead, we used the biological indicators as co-variates together with the environmental co-variates (Section 2.9 and Table 2).

\subsection{Fractionation of soil organic matter}

All samples were air-dried, crushed using a pestle and mortar and sieved at $2 \mathrm{~mm}$ in agreement with the protocols for routine soil fertility analysis (Genot et al., 2011). For fractionation, $10 \mathrm{~g}$ of fine earth $(<2 \mathrm{~mm}$ ) was mixed with $100 \mathrm{ml}$ of de-ionized water in a plastic bottle and shaken horizontally for $15 \mathrm{~min}$ at $250 \mathrm{rpm}$. The fine earth water mixture was then quantitatively transferred to a $50 \mu \mathrm{m}$ sieve and washed through in a beaker until the liquid that passed the sieve was clear. The material that passed through the $50 \mu \mathrm{m}$ sieve was then poured onto a $20 \mu \mathrm{m}$ sieve and washed through using a spray bottle filled with deionized water and a rubber spatula until the liquid that passed the sieve was clear. The first sieving step was included in order to prevent the clogging of the finest sieve. Care was taken to keep the total amount of water used for shaking and washing below $2 \mathrm{dm}^{3}$, in order to reduce losses during centrifugation and drying. The fraction remaining on the sieves was collected and dried in an oven at $60^{\circ} \mathrm{C}$. The liquid finer than $20 \mu \mathrm{m}$ was centrifuged for $25 \mathrm{~min}$ at $3600 \mathrm{rpm}$ and the clear supernatant discarded. The remainder was transferred into a beaker and dried at $60{ }^{\circ} \mathrm{C}$ for four days minimum. The mean recovery rate was $96 \%$.

The fine earth $(<2 \mathrm{~mm})$ as well as the fine fraction $(<20 \mu \mathrm{m})$ were 
Table 2

Environmental co-variates.

\begin{tabular}{|c|c|c|c|}
\hline $\begin{array}{l}\text { Variable } \\
\text { Topography }\end{array}$ & Explanation & Depth $(\mathrm{cm})$ & Reference \\
\hline eastness & Aspect, orientation towards East (Zar, 1999) & - & \multirow{8}{*}{$\begin{array}{l}\text { Derived from a } 20 \mathrm{~m} \text { resolution DEM provided by the NGI (Chartin et al., } \\
\text { 2017) }\end{array}$} \\
\hline northness & Aspect, orientation towards North (Zar, 1999) & - & \\
\hline TPI $500 \mathrm{~m}$ & Topographical position Index (Jenness, 2006) & - & \\
\hline Flow length & Flow length according to RUSLE & - & \\
\hline C factor & Crop factor according to RUSLE & - & \\
\hline slope & Slope gradient $(\%)$ & - & \\
\hline dem & Elevation (m) & - & \\
\hline Climate & & - & \\
\hline Precipitation & Precipitation (mm) & - & \multirow{2}{*}{$\begin{array}{l}\text { Annual mean data (1971-2000) from meteo stations in Belgium and } \\
\text { neighbouring countries, maps modelled using elevation from NASA SRTM } \\
\text { DEM (Chartin et al., 2017) }\end{array}$} \\
\hline Temp & Mean temperature $\left({ }^{\circ} \mathrm{C}\right)$ & - & \\
\hline \multicolumn{4}{|r|}{$\mathrm{x}^{-3}$} \\
\hline clay & Clay (\%) & $0-20$ & \multirow{3}{*}{$\begin{array}{l}\text { Maps of clay, silt and sand based on regression kriging of Aardewerk data } \\
\text { (Chartin et al., 2017) }\end{array}$} \\
\hline silt & Silt $(\%)$ & $0-20$ & \\
\hline sand & Sand (\%) & $0-20$ & \\
\hline $\mathrm{pH}$ & $\mathrm{pH} \mathrm{KCl}$ & $0-10$ & This study see section 2.9 \\
\hline GWL min & Winter groundwater level (cm) & - & \multirow[t]{2}{*}{ Based on Aardewerk database (Meersmans et al., 2008) } \\
\hline GWL max & Summer groundwater level $(\mathrm{cm})$ & - & \\
\hline \multicolumn{4}{|l|}{ Land use } \\
\hline Land use & Grassland/cropland & - & Observations at sampling sites \\
\hline FYM & $\begin{array}{l}\text { Input of farmyard manure (and slurry) per municipality } \\
\left(\mathrm{MgC} \mathrm{ha} \mathrm{y}^{-1} \mathrm{y}^{-1}\right)\end{array}$ & - & Based on Dendoncker et al. (2004). Raster image with $40 \mathrm{~m}$ pixel \\
\hline \multicolumn{4}{|c|}{ Biological indicators } \\
\hline MBC & Microbial biomass C (mg C/kg) & $0-10$ & This study see section 2.8 \\
\hline MBN & Microbial biomass N (mg N/kg & $0-10$ & This study see section 2.8 \\
\hline PR & $\begin{array}{l}\text { Potential respiration after } 16 \mathrm{~h} \text { pre-incubation at } 15^{\circ} \mathrm{C} \text { and } \\
55 \% \text { field capacity }\left(\mathrm{mg} \mathrm{C}-\mathrm{CO}_{2} \mathrm{~kg}^{-1} \text { hour }^{-1}\right)\end{array}$ & $0-10$ & \\
\hline Nmin & Net $\mathrm{N}$ mineralization $\left(\mathrm{mg} \mathrm{N} \mathrm{kg}^{-1} \mathrm{day}^{-1}\right.$ ) & $0-10$ & \\
\hline Biolog & Functional diversity (\%) & $0-10$ & \\
\hline qmic & Microbial quotient (MBC/SOC, unitless) & $0-10$ & \\
\hline $\mathrm{qCO}_{2}$ & Metabolic quotient (PR/MBC, mg C- $\mathrm{CO}_{2} \mathrm{~kg}^{-1} \mathrm{C} \mathrm{h}^{-1}$ ) & $0-10$ & \\
\hline
\end{tabular}

analyzed for their concentration of organic carbon. The $\mathrm{C}$ concentration of the coarse fraction $(>20 \mu \mathrm{m})$ was calculated from its mass and the mass and $\mathrm{C}$ concentrations of the fine earth and the fine fraction. All samples were tested for the presence of inorganic C (Ci) as calcium carbonate using a $5 \% \mathrm{HCl}$ solution. Dolomite only occurs in Keuper limestones with a very limited outcrop on the border of the Jura and the Ardenne (Fig. 1; Boulvain and Pingot, 2013). As no samples originated from this area, a correction for dolomite was not required. If inorganic $\mathrm{C}$ was present, its content was determined by the calcimetric method using an electronic manometer (Sherrod et al., 2002). Carbon (Ci + o) was analyzed by dry combustion using a VarioMax CN Analyzer (Elementar GmbH, Germany). Finally, soil organic C concentration was calculated from the difference between total C and inorganic C (Eq. 1):

$\mathrm{SOC}=\mathrm{Ci}+\mathrm{o}-\mathrm{Ci}$

where all concentrations are expressed in $\mathrm{g} \mathrm{kg}^{-1}$.

Duplicates were fractionated for five samples, and the RMSE of the SOC content in the fine fraction was $0.45 \mathrm{~g} \mathrm{C} \mathrm{kg}^{-1}$ soil.

Twenty samples that were also treated by the shaking and sieving method described above were fractionated according to the scheme of Hassink (1997). The samples were selected in order to cover the range in SOC content of the soil monitoring network. Here, $20 \mathrm{~g}$ fine earth was dispersed in $150 \mathrm{ml}$ deionized water and then sonified at $100 \mathrm{~J} \mathrm{ml}^{-1}$. The probe type sonicator (Branson 250) was calibrated to a power of $43.58 \mathrm{~W}$ over $344 \mathrm{~s}$. The $500 \mathrm{ml}$ beaker $(86 \times 181 \mathrm{~mm})$ was cooled in a water bath with ice cubes in order to prevent heat build-up. We then sieved the soil-water mixture over $20 \mu \mathrm{m}$ under pressure and rinsing with de-ionized water until the liquid was clear. The liquid finer than $20 \mu \mathrm{m}$ was evaporated and freeze-dried. The mean recovery rate was $97 \%$. The SOC content of the fine earth and the fraction finer than $20 \mu \mathrm{m}$ was determined as explained above.

\subsection{Biological indicators}

Microbial C and N concentrations were measured after fumigation with chloroform (Vance et al., 1987). To do this, $20 \mathrm{~g}$ of non-fumigated soil and $20 \mathrm{~g}$ of fumigated soil ( $72 \mathrm{~h}$ with chloroform) were extracted with $100 \mathrm{ml} \mathrm{K}_{2} \mathrm{SO}_{4}(0.5 \mathrm{M})$ for one hour $(180 \mathrm{rpm})$ and the supernatant was filtered (Whatman 42). Total $\mathrm{N}$ was measured colorimetrically with an auto-analyser equipped with a UV digester (Auto-Analyzer 3, Bran + Luebbe, Germany). Organic C was measured with an infrared analysis system (LABTOC, Pollution \& Process Monitoring, UK). Biomass C- and N-pools were calculated as difference between organic $\mathrm{C}$ contents and total $\mathrm{N}$ contents of fumigated and non-fumigated soil extracts by the relationships (Eqs. 2 and 3):

$\mathrm{MBC}=\mathrm{E}_{\mathrm{c}}$ fumigated soil $-\mathrm{E}_{\mathrm{C}}$ non-fumigated soil $/ \mathrm{k}_{\mathrm{EC}}$

$\mathrm{MBN}=\mathrm{E}_{\mathrm{N}}$ fumigated soil $-\mathrm{E}_{\mathrm{N}}$ non-fumigated soil $/ \mathrm{k}_{\mathrm{EN}}$

Where MBC and MBN are the microbial biomass $C$ and $N\left(\mathrm{mg} \mathrm{kg}^{-1}\right), \mathrm{E}_{\mathrm{C}}$ and $\mathrm{E}_{\mathrm{N}}$ the $\mathrm{C}$ and $\mathrm{N}$ extracted and $\mathrm{k}_{\mathrm{EC}}$ and $\mathrm{k}_{\mathrm{EN}}$ the conversion factors of 0.45 for C (Jenkinson et al., 2004) and 0.54 for N (Joergensen and Mueller, 1996).

Net nitrogen mineralization (Nmin) was calculated as the difference in mineral $\mathrm{N}$ concentration (nitrate, N-NO3- and ammonium, N-NH4) in a $40 \mathrm{ml} \mathrm{KCl}(1 \mathrm{M})$ extract before and after an incubation of $20 \mathrm{~g}$ fresh soil without roots during 29 days at $25^{\circ} \mathrm{C}$ in the dark (Hart et al., 1994). The extracts were centrifuged for $10 \mathrm{~min}$ at $3000 \mathrm{rpm}$ and the supernatant stored frozen until analysis. The N-NO3- and N-NH4 concentrations were measured using an auto-analyzer (Auto-Analyzer 3, Bran + Luebbe, Germany). $\mathrm{N}$ mineralization is expressed in $\mathrm{mg} \mathrm{N} \mathrm{kg}^{-1}$ day $^{-1}$.

The respiration potential (PR) was measured on fresh soil adjusted to $55 \%$ of field capacity after $16 \mathrm{~h}$ at $15^{\circ} \mathrm{C}$. The soil respiration was 


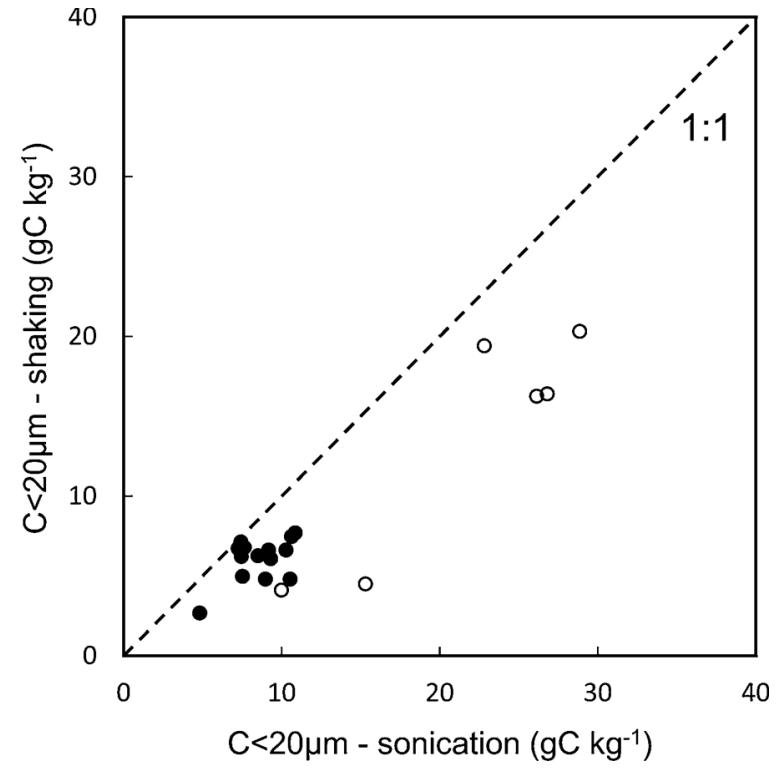

Fig. 2. Comparison of concentration of $\mathrm{C}<20 \mu \mathrm{m}$ between two fractionation techniques in a selection of croplands (closed symbols) and grasslands (open symbols): shaking (as applied in this study) and after sonication of $20 \mathrm{~g}$ soil in $150 \mathrm{ml}$ water with an energy of $100 \mathrm{~J} \mathrm{ml}^{-1}$ (energy level specified by Hassink, 1997).

determined by measuring the $\mathrm{CO}_{2}$ accumulation produced by $20 \mathrm{~g}$ of soil in a $250 \mathrm{ml}$ bottle. Gas samples of $4 \mathrm{ml}$ were taken at $0,120,240$ and $360 \mathrm{~min}$ incubation and were analyzed by infrared absorption (EGM-4, PPsystem, UK). The rate of $\mathrm{CO}_{2}$ production was calculated by linear regression and expressed in $\mathrm{mg} \mathrm{C}-\mathrm{CO}_{2} \mathrm{~kg}^{-1} \mathrm{~h}^{-1}$.

The functional or metabolic potential of the bacteria (Biolog) was measured using Biolog Ecoplates (BIOLOG ${ }^{\mathrm{Tm}}$, California) containing 31 carbonated substrates. One gram of fresh soil was extracted with $9 \mathrm{ml}$ of sodium chlorate (Rutgers et al., 2009). In order to evaluate the size of the microbial community, three dilutions (10-2, 10-3 and 10-4) were established in a $0.85 \% \mathrm{NaCl}$ solution. A dilution corresponding to 1000-2000 CFU (colony forming units) was used for incubation. The Biolog plates were incubated for $72 \mathrm{~h}$ at $20^{\circ} \mathrm{C}$ and the substrates with visible reactions were identified. The functional diversity was expressed as percentage of substrates used by the bacteria.

The microbial quotient (qmic) can be used as an index for the availability of carbon for micro-organisms (Bimüller et al., 2014). The quotient is calculated as the ratio MBC in $\mathrm{g} \mathrm{C} \mathrm{kg}^{-1}$ and the organic $\mathrm{C}$ in the bulk soil (Ctot in $\mathrm{g} \mathrm{C} \mathrm{kg}^{-1}$; Eq. 4) :

qmic $=\mathrm{MBC} /$ Ctot

The metabolic quotient $\left(\mathrm{qCO}_{2}\right)$ is an indicator for the energy required to maintain the microbial biomass (Anderson and Domsch, 1993). High values point to a stressed microbial community. The metabolic quotient is the ratio between the potential respiration (PR in $\mathrm{mg}$ $\left.\mathrm{C}-\mathrm{CO}_{2} \mathrm{~kg}^{-1} \mathrm{~h}^{-1}\right)$ and the $\mathrm{MBC}(\mathrm{g} \mathrm{C} \mathrm{kg}-1)$ and is expressed in $\mathrm{mg}$ $\mathrm{C}-\mathrm{CO}_{2} \mathrm{~kg}^{-1} \mathrm{C} \mathrm{h}^{-1}$ (Eq.5):

$\mathrm{qCO}_{2}=\mathrm{PR} / \mathrm{MBC}$

\subsection{Environmental co-variates}

The co-variates are subdivided in the following categories: climate, soil, land use and biological indicators. Soil $\mathrm{pH}$ was measured in a suspension (1:2 w:w) of $1 \mathrm{M} \mathrm{KCl}$ using a pH meter (HI2550 Hanna Instruments). Apart from the $\mathrm{pH}$, the climate and soil related co-variates were derived at the 89 sites from thematic maps (Table 2). The upstream flow length and crop cover (C) factor were used as in the RUSLE equation (Renard et al., 1991).

\subsection{Data analysis}

\subsubsection{Conditional inference tree ensemble}

In order to characterize the fractions and to understand their drivers we applied a conditional inference forest analysis with the $\mathrm{C}<20 \mu \mathrm{m}$, $\mathrm{C}>20 \mu \mathrm{m}$ as dependent variables. Conditional inference trees are similar to a random forest and can be used to model non-linear interactions between the response variable (i.e. the $\mathrm{C}$ fractions) and predictor variables (see Table 2) without the requirements of normality and homoscedasticity (Hobley et al., 2016). In principle, all sites with a complete dataset were used. As some of the sites, in particular the longterm trials and paired sites, contained replicates of the samples, first an average from these replicates was calculated. All models were created using the party package in $\mathrm{R}$ (Strobl et al., 2007). The conditional inference forest was grown over 500 trees with the number of predictor variables randomly selected per split set to 2 and a significance relationship between predictor and response variable at $\alpha<0.05$. Overall, the data set contained 89 observations and 24 predictor variables (Table 2). The overall performance of the models was evaluated on the RMSE and $\mathrm{R}^{2}$ of the out-of-bag dataset. The relative variable importance (Hobley et al., 2015) was expressed as $n=I / T * 100$, where $\mathrm{I}$ is the variable importance and $\mathrm{T}$ is the total variance explained by the model.

\subsubsection{Differences between treatments and correlation matrix}

For contrasts of long-term trials or paired plots with more than two treatments, the differences in Ctot, $\mathrm{C}<20 \mu \mathrm{m}$ and $\mathrm{C}>20 \mu \mathrm{m}$ between treatments were tested using permutation-based ANOVA (i.e., with treatment as between-subjects factor). A correlation matrix between the 23 environmental covariates (all variables in Table 2 except land use) and SOC fractions was calculated using the Pearson $r$. The significance level of all statistical tests was set at $\alpha=0.05$.

\section{Results and discussion}

\subsection{Factors controlling the concentration of the fractions}

The comparison of both fractionation methods i.e. with and without sonication showed that the latter method yields ca $30 \%$ higher C $<20 \mu \mathrm{m}$ concentrations (Fig. 2). This implies that a portion of fine micro-aggregates and primary particles $(<20 \mu \mathrm{m})$ remain encapsulated within large micro-aggregates $(20-250 \mu \mathrm{m})$ after shaking. SOM fractionation protocols are sensitive to the disruptive power applied in order to separate the fractions (Poeplau and Don, 2014). We shook the sample for $15 \mathrm{~min}$ and thus cannot report the energy level. However, shaking is considered to be less disruptive than sonication, peptization or using a ball mill. Since the fractionation included neither sonication nor peptization, the protocol could be classified as an aggregate fractionation according to the classification of Poeplau et al. (2018). In contrast to the slaking procedure first suggested by Six et al. (2002) and adapted by Stewart et al. (2008), shaking for $15 \mathrm{~min}$ at $250 \mathrm{rpm}$ probably destroys the macro aggregates ( $>250 \mu \mathrm{m}$ ) but was not aggressive enough to destroy micro aggregates (Balesdent, 1996).

Within the agricultural regions the site selection was stratified according to landscape units with a similar soil texture, drainage and stoniness class (section 2.2; Fig. 3). Overall, with an increase in Ctot the contribution of the $\mathrm{C}>20 \mu \mathrm{m}$ in croplands increased from the NW to the $\mathrm{SE}$ at the expense of the $\mathrm{C}<20 \mu \mathrm{m}$ fraction. In grasslands, Ctot remained more or less constant with an increase in $\mathrm{C}<20 \mu \mathrm{m}$ resulting in a relative decrease of $C>20 \mu \mathrm{m}$. These general NW-SE trends correspond to increasing clay content, decreasing temperature and increasing precipitation (Meersmans et al., 2016; Chartin et al., 2017). The highest $C<20 \mu \mathrm{m}$ contents in the Famenne grasslands are 

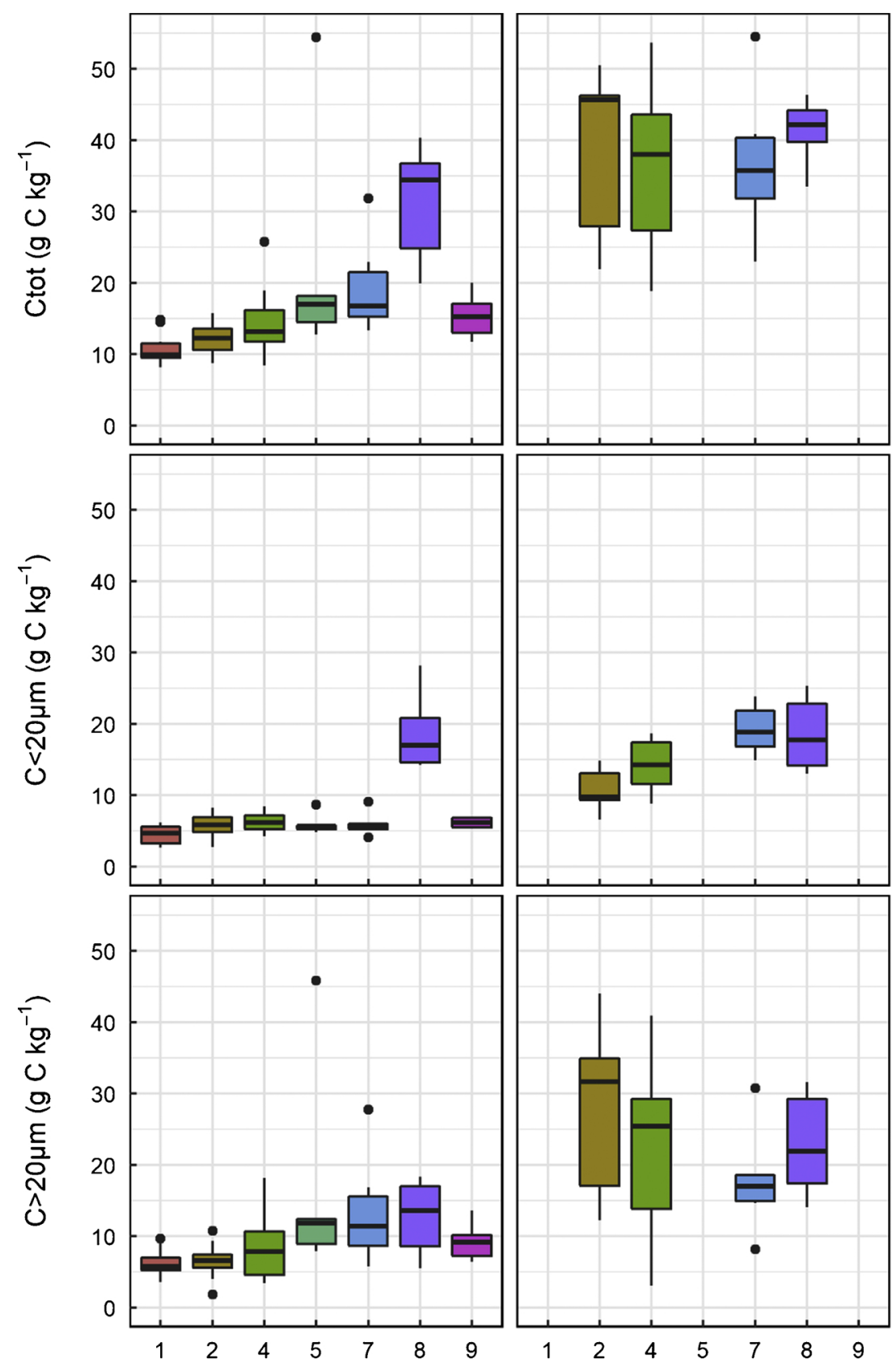

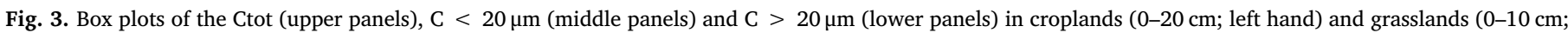

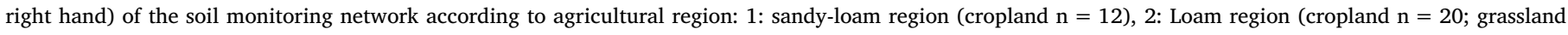

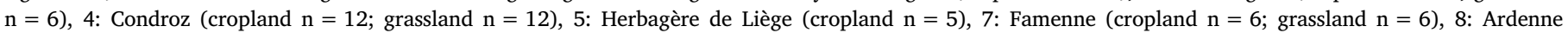
(cropland $n=6$; grassland $n=6$ ), 9: Jura(cropland $n=6$ ). See Fig. 1 for a map of the agricultural regions.

consistent with the overall high clay content, low temperature and high precipitation in this region, whereas the lower contents in the loam region correspond to the lower clay content and lower precipitation at higher temperatures. These clear regional trends under grassland are in agreement with the theory of Hassink (1997) and Feng et al. (2013), who argued that the fine $\mathrm{C}$ fraction is associated with clay and fine silt. However, it should be noted that the clay content, precipitation and temperature all show similar gradients and there is a need for multifactorial experiments to unravel the influence of each factor. The higher content of $\mathrm{C}<20 \mu \mathrm{m}$ in clay soils is therefore consistent with a higher storage capacity in the fine fraction due to their greater specific surface area combined with the greater relative abundance in heavy textured soils. In contrast, the total storage of $\mathrm{C}<20 \mu \mathrm{m}$ in light textured soils was limited due to the greater number of coarser particles in these soils

\section{(Hobley et al., 2013).}

In contrast to the grasslands, there was no clear trend in $C<20 \mu \mathrm{m}$ in the croplands, but concentrations were generally low (Fig. 3). This is consistent with lower C inputs into the croplands $(1.93-2.15 \mathrm{Mg} \mathrm{C}$ $\mathrm{ha}^{-1} \mathrm{y}^{-1}$, van Wesemael et al., 2010) compared to the grasslands (2.9 $\left.\mathrm{Mg} \mathrm{C} \mathrm{ha} \mathrm{h}^{-1} \mathrm{y}^{-1}\right)$, and indicates that additional C storage capacity exists in the fine fraction of the croplands. However, the higher C $>20 \mu \mathrm{m}$ in the grasslands than in the croplands indicates that this fraction is also depleted and has further C storage potential. This is consistent with $\mathrm{C}$ losses under croplands across both fractions, indicating that both fractions are sensitive to land-use (Hobley et al., 2016). Despite the lack of a clear regional trend in $C<20 \mu \mathrm{m}$, the C $>20 \mu \mathrm{m}$ in croplands showed a regional-climatic trend corresponding to increase in precipitation and decrease in temperature from 


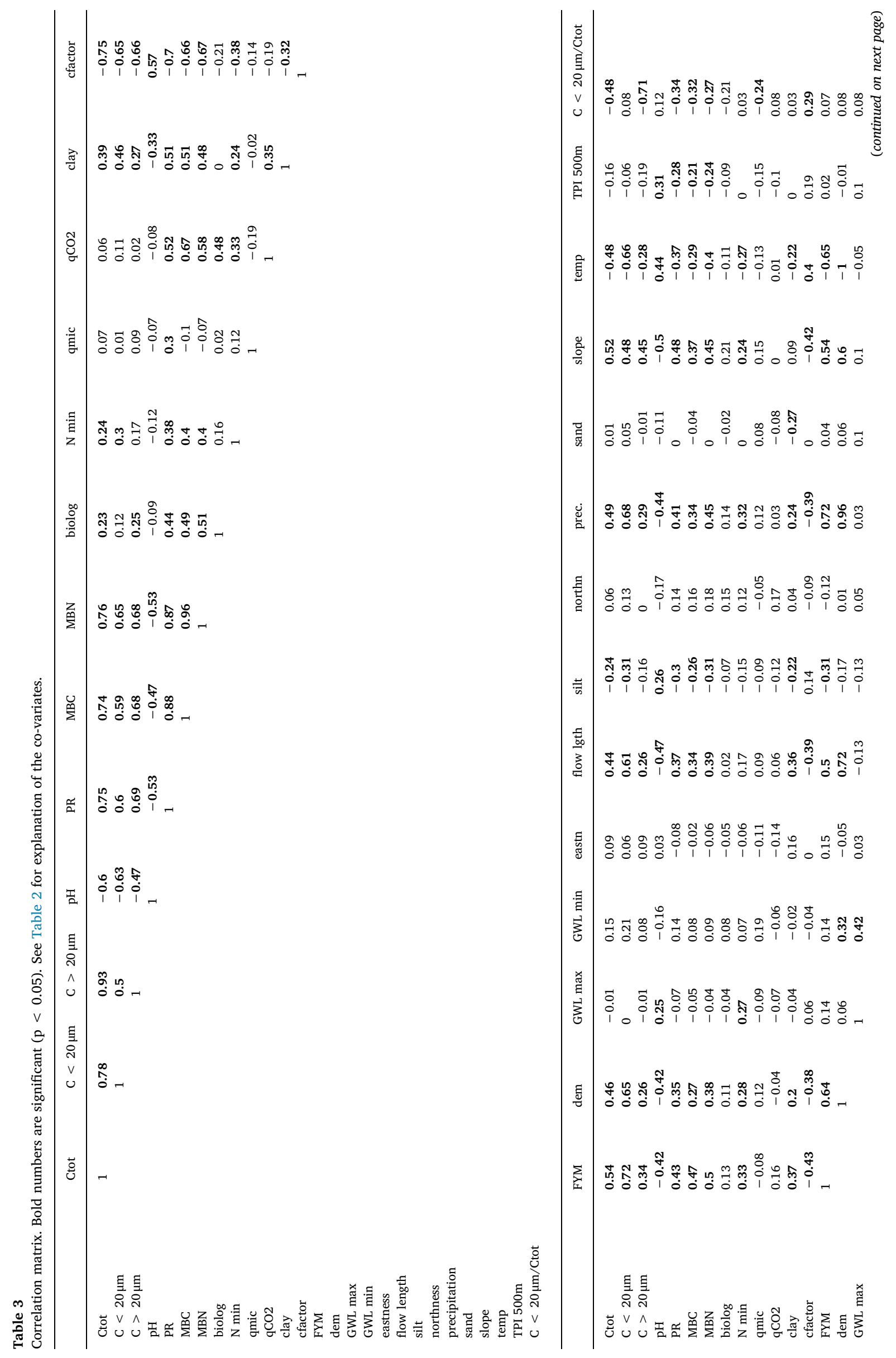


the NW to the SE, suggesting that this fraction is sensitive to climatecontrolled inputs ( $\mathrm{C}$ inputs from crop residues: sand loam region: $2.07 \mathrm{Mg} \mathrm{C} \mathrm{ha}{ }^{-1} \mathrm{y}^{-1}$, loam region: $1.93 \mathrm{Mg} \mathrm{C} \mathrm{ha}{ }^{-1} \mathrm{y}^{-1}$, Condroz: $2.06 \mathrm{Mg} \mathrm{C} \mathrm{ha}^{-1} \mathrm{y}^{-1}$, Ardenne: $2.15 \mathrm{Mg} \mathrm{C} \mathrm{ha}^{-1} \mathrm{y}^{-1}$; van Wesemael et al., 2010).

The conditional inference forest model performed better at explaining the $\mathrm{C}<20 \mu \mathrm{m}$ than the $\mathrm{C}>20 \mu \mathrm{m}$, accounting for $63 \%$ of variance in the former, but only $44 \%$ of variance in the latter. Although the predictive performance may be improved by not constraining the minimum criterion for a split (Hobley and Wilson, 2016), our focus was on identifying predictors with statistically significant relationships with the fractions, which was ensured by this modelling approach. Note that due to the very strong correlation of temperature and elevation with precipitation (Table 3), we only included precipitation as a potential predictor in the models.

The microbial biomass $\mathrm{N}$ concentration proved to be the most important factor explaining $\mathrm{C}$ storage in both fractions (Fig. 4). This result suggests that $\mathrm{C}$-storage is not only constrained by C-inputs (as indicated by the difference between grasslands: $2.9 \mathrm{Mg} \mathrm{Cha}^{-1} \mathrm{y}^{-1}$ and croplands: $1.93-2.15 \mathrm{Mg} \mathrm{C}$ ha $^{-1} \mathrm{y}^{-1}$ van Wesemael et al., 2010) but that constraints on microbial activity, such as $\mathrm{N}$ limitation can also influence SOM storage (Allison et al., 2010; Craine et al., 2007; Fontaine et al., 2004; Kirkby et al., 2014). Although, the microbial biomass C and N were strongly correlated, the greater influences of MBN on C storage suggests an overall $\mathrm{N}$ limitation in the region. In particular, only five variables were identified as important to predicting $\mathrm{C}>20 \mu \mathrm{m}$ (Fig. 4), namely microbial $\mathrm{N}$ and $\mathrm{C}$, land use, respiration and crop cover as approximated by the $\mathrm{C}$ factor of the RUSLE, of which the three most important variables were related with microbial activity. This indicates a close relationship between more labile $\mathrm{C}>20 \mu \mathrm{m}$ with potential respiration and land-use. The higher $C>20 \mu \mathrm{m}$ in grasslands than croplands reflects the difference in $\mathrm{C}$ inputs in these systems (see data on $\mathrm{C}$ input in previous paragraph), whereas the microbial parameters indicate close association of less stable $C>20 \mu \mathrm{m}$ with potential respiration. However, whether $\mathrm{C}$ storage controls microbial activity, viceversa, or they are co-dependent could not be concluded from this analysis.

In contrast to the relatively simple controls on $\mathrm{C}>20 \mu \mathrm{m}$, $\mathrm{C}<20 \mu \mathrm{m}$ was also associated with environmental and management co-variates such as carbon input from farmyard manure and slurry (FYM), precipitation at the regional scale, and upstream flow length as a proxy for fluxes of sediment and water at the catchment scale. Flow length has been associated with SOC spatial distribution in the region, as result of its effect on erosion and sedimentation, and relationship with elevation $(\rho=0.29)$ and therefore precipitation, which influences long-term productivity (Chartin et al., 2017). The importance of FYM and slurry to $C<20 \mu \mathrm{m}$ suggests that the application of farm fertilizers leaded to their incorporation and retention into fine soil particles. Overall, these co-variates important to $\mathrm{C}<20 \mu \mathrm{m}$ (FYM, slurry, precipitation and flow length) are indicative of the balance of $\mathrm{C}$ input and decomposition over longer time scales and it is thus not surprising to find them as explanatory variables for a more stabilized fraction.

Overall, the conditional inference forest selected those variables with strongest relationships with the fractions, which is consistent with the constraint to significance imposed within the algorithm. The selected variables themselves were often correlated with many other variables, often indicating conditions favouring the input of biomass and retarding decomposition (Table 3). An example of such covariance between the variables selected by the conditional inference forests is the ratio of microbial biomass $\mathrm{C}$ to Ctot (qmic), which was positively correlated to potential respiration (PR), microbial biomass N (MBN), $\mathrm{N}$ mineralization (Nmin) and clay content. The negative correlation between the proportion of $\mathrm{C}<20 \mu \mathrm{m}$ and Ctot indicates that this fraction was important at low Ctot contents (Table 3; Hobley et al., 2013). 

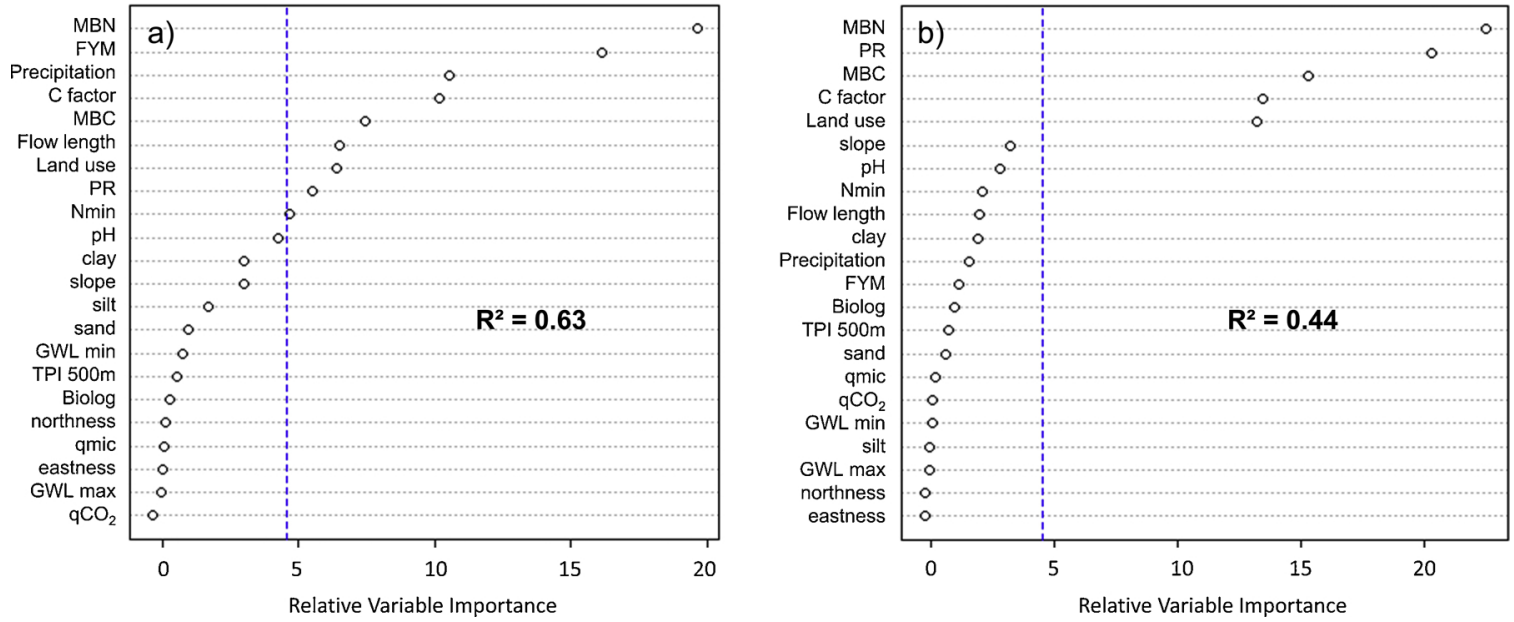

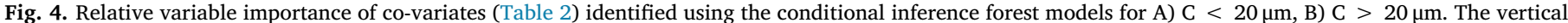
dashed lines indicates the average variable importance including all 22 covariates.

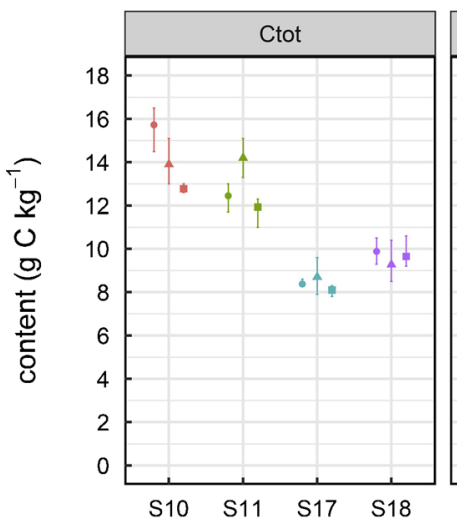

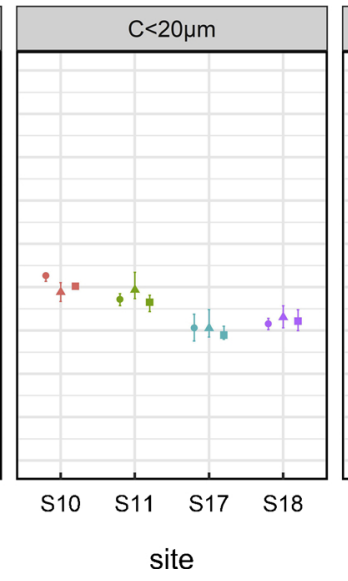

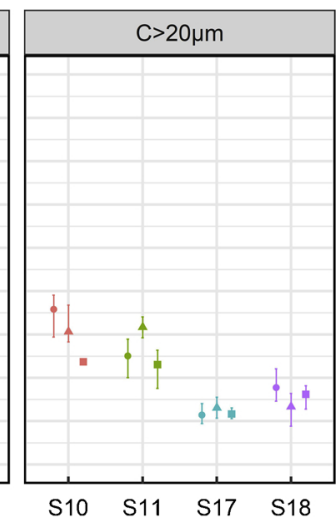

Fig. 5. Seasonal variability in Ctot and SOM fractions for sites with no-till (S10), shallow tillage (S11), long-term experiment (control S17 and cover crops S18). Sampling dates: April 2016 (diamonds), June 2016 (triangles), August 2016 (squares). The error bars represent the minimum and maximum values $(\mathrm{n}=4$ for each point).

\subsection{Sensitivity of fractions to agricultural management}

SOM fractions were analysed in April, June and August for two sites under conservation agriculture (see section 2.3) and a control as well as an organic amendment treatment of the long-term trial in Long Tours (see section 2.3; Fig. 5). Overall, the differences between the seasons were smallest for the $\mathrm{C}<20 \mu \mathrm{m}$. For the $\mathrm{C}>20 \mu \mathrm{m}$, there were no systematic differences between the seasons. The variability of Ctot reflected the trends in $\mathrm{C}>20 \mu \mathrm{m}$, indicating that the coarse fraction was more sensitive to short-term influences on $\mathrm{C}$ dynamics, and this is
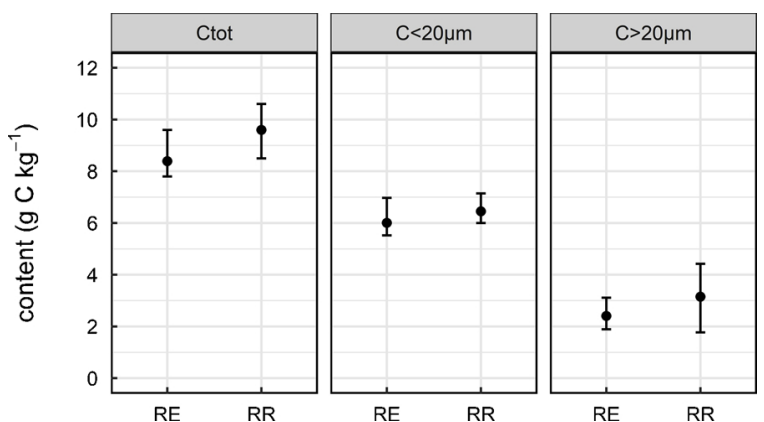

Fig. 6. Long-term trial on organic amendments set up in 1959; RE: Residue export without organic fertilizer, RR: Residue restitution and cover crop (see Section 2.3). The error bars represent the minimum and maximum values ( $n=12$ for each treatment). reflected in Ctot concentration. Although sampling to a fixed depth of $20 \mathrm{~cm}$ did not account for any settling effects after tillage, there appeared to be no clear trends and thus no reason to restrict sampling to a specific season.

The sampling throughout the seasons in the long-term trial of Long Tours provided a total number of 12 samples (i.e. 3 seasons and 4 replicates between the control (residue export) and the treatment with residue restitution and a cover crop once every three years in the rotation (Section 2.3; Fig. 6)). Despite high variability, particularly in C $>20 \mu \mathrm{m}$, ploughing in of residues increased C contents in the coarse and fine fractions, as well as Ctot (Fig. 6). Although both fractions responded positively to residue restitution, the effect was less pronounced in $C<20 \mu \mathrm{m}$ than in $\mathrm{C}>20 \mu \mathrm{m}$. This is consistent with a greater sensitivity to management in $\mathrm{C}>20 \mu \mathrm{m}$ than in $\mathrm{C}<20 \mu \mathrm{m}$. This corresponds with the findings of Trigalet et al. (2014), who investigated the same treatments using samples from 1970 and 2012 and did not observe any differences between treatments in the fine fraction sampled in 1970. This confirms that increases in the fine fraction are relatively slow and require a sustained supply of $\mathrm{C}$ from the coarse fraction, where the differences between treatments are larger and occur more rapidly. Furthermore, this suggests that $\mathrm{C}<20 \mu \mathrm{m}$ is (at least partly) derived from a portion of $\mathrm{C}>20 \mu \mathrm{m}$, namely the $\mathrm{C}$ which is not lost as $\mathrm{CO}_{2}$ to the atmosphere but is biophysico-chemically altered and incorporated into the fine soil matrix.

The trial in Gentinnes consisted of three treatments including a cover crop and residue return to the soil, but with different tillage management (Section 2.3; Fig. 7). The effect of the tillage depth 


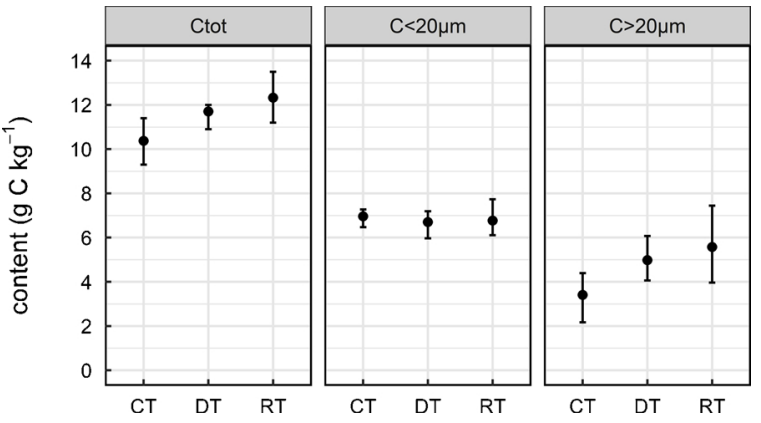

Fig. 7. Long-term trial (set up in 2005) with mouldboard tillage (CT), cultivator tine until $30 \mathrm{~cm}(\mathrm{DT})$ and spring tine cultivator until $10 \mathrm{~cm}$ (RT). The error bars represent the minimum and maximum values $(n=4$ for each treatment).

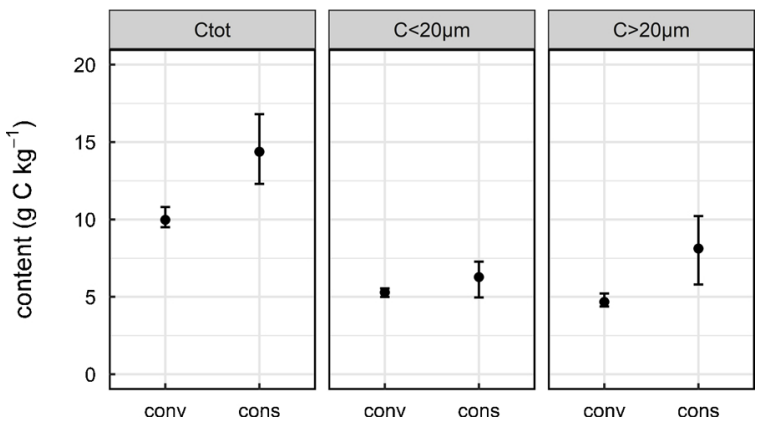

Fig. 8. Paired sites in farmers' fields with conventional (conv; 1 site) and conservation agriculture (cons; 2 sites) for at least 10 years $(n=12)$. The error bars represent the minimum and maximum values.

(mouldboard (CT) vs heavy tine cultivator until $30 \mathrm{~cm}$ (DT) and spring tine cultivator until $10 \mathrm{~cm}$ (RT)) can be seen from the higher $\mathrm{C}>20 \mu \mathrm{m}$ in the conservation treatments (i.e. DT and RT) (Fig. 7). This difference can be explained by the shallower tillage depth and the incomplete mixing of the plough layer by using the heavy tine cultivator (DT). However, in contrast to the trial in Long Tours that started in 1959, the length of the trial in Gentinnes (established in 2005) had not yet led to changes in $C<20 \mu \mathrm{m}$. Thus, the increase in $\mathrm{C}$ due to reduced tillage management occurred in $C>20 \mu \mathrm{m}$, consistent with its characterization as a short to mid-term management-sensitive indicator of C. It should be noted that a small bias is to be expected as the C concentration is no longer uniformly mixed throughout the $27 \mathrm{~cm}$ thick plough layer, but will be concentrated in the sampled 0-20 cm topsoil.

In contrast to the Gentinnes trial, the paired plot approach demonstrated that fields converted to conservation agriculture for at least 10 years had higher $\mathrm{C}<20 \mu \mathrm{m}$ concentrations (Fig. 8). This difference could be explained by the fact that farmers in general changed not only their tillage system (as in Gentinnes), but also increased the use of cover crops and crop residues (see Section 2.3). In fact, the difference in $\mathrm{C}>20 \mu \mathrm{m}$ between treatments for the paired plots $\left(3.0 \mathrm{~g} \mathrm{C} \mathrm{kg}^{-1}\right)$ was somewhat higher than for the Gentinnes trial $\left(2.0-2.5 \mathrm{~g} \mathrm{C} \mathrm{kg}^{-1}\right)$.

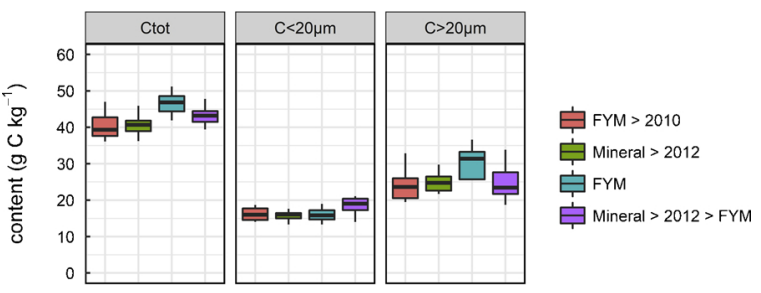

Fig. 9. Box plot of long-term trial on grassland fertilization set up in 1996. Organic farming started and mineral fertilization stopped in 2012 ( $\mathrm{n}=8$ for each treatment).
Overall, differences in $\mathrm{C}<20 \mu \mathrm{m}$ between control and the treatments were observed over periods of 5-10 years only when the ratio C $>20 \mu \mathrm{m} /$ Ctot was greater than 0.5 . These results indicate that management can affect $C<20 \mu \mathrm{m}$ over shorter time-periods, but that high inputs of coarse SOM are required to drive the production of fine $\mathrm{SOM}$ and its incorporation into the soil matrix in the longer term.

For the grasslands, the $\mathrm{C}<20 \mu \mathrm{m}\left(12-20 \mathrm{~g} \mathrm{C} \mathrm{kg}^{-1}\right)$ was rather high (Figs. 9 and 10). Moreover, the variability in $C<20 \mu \mathrm{m}$ across the 49 sites of the Bioecosys network (Table 1 ) and the four treatments in Libramont was quite small (Figs. 9 and 10; Table 4). The proportion of $\mathrm{C}>20 \mu \mathrm{m}$ was also higher in the grasslands (0.57-0.79) compared to the croplands (0.45-0.59). This large and relatively constant $\mathrm{C}<20 \mu \mathrm{m}$ and high proportion of $\mathrm{C}>20 \mu \mathrm{m}$ for sites mainly in the Ardenne where the soil texture is relatively clayey suggests that these soils are well supplied by $\mathrm{C}$ input and may be close to their C saturation as first defined by Hassink (1997). Thus, changes in management will likely not further increase the $\mathrm{C}<20 \mu \mathrm{m}$ fraction, but be reflected in the $\mathrm{C}>20 \mu \mathrm{m}$ fraction. In fact, the treatment receiving composted manure clearly had the highest $\mathrm{C}>20 \mu \mathrm{m}$ in Libramont (Fig. 9). For the grasslands in the Ardenne, there was a general trend of increasing C $>20 \mu \mathrm{m}$ with decreasing management intensity (Fig. 10). The differences between conventional (Mt1) and organic temporary grasslands (Mt2) were clear as well as the gradient in the grazed grasslands with increasing restrictions on cattle number and organic amendments (Gp1Gp3; Fig. 10, Table 4). In summary, more intensively managed grasslands were generally associated with lower Ctot contents, with the reactive fraction being $\mathrm{C}>20 \mu \mathrm{m}$, but the overall high inputs of $\mathrm{C}$ into grasslands systems indicate a saturation in $C<20 \mu \mathrm{m}$, so that it is not management sensitive. However, caution is required when comparing the results in the croplands and grasslands due to the differences in sampling depth, so that further research is required in order to substantiate the results.

\subsection{SOC fractions as indicators for agricultural management}

From the previous sections it appeared that the $C<20 \mu \mathrm{m}$ represents a relatively stable fraction that is associated with the mineral complexes. The concentration of this fraction was highest in grassland soils, where at the same time the $\mathrm{C}>20 \mu \mathrm{m}$ concentrations were high (Fig. 3). This indicates that a large input of $\mathrm{C}$ is required to increase and maintain fine $\mathrm{C}$ storage. Long-term trials in cropland demonstrated that the coarse fraction $(\mathrm{C}>20 \mu \mathrm{m})$ reacts to conservation tillage treatments started in 2008 (DT and RT; Fig. 7), but that the mineral associated fraction $(\mathrm{C}<20 \mu \mathrm{m})$ had not yet reacted to these treatments. The relative change in Ctot over the last $\sim 10$ years (C_ER: enrichment ratio in Ctot) was assessed in 60 sites that were first sampled in 2005 and re-sampled in 2015 (see section 2.3). The ratio of $\mathrm{C}>20 \mu \mathrm{m}$ to $\mathrm{C}<20 \mu \mathrm{m}$ (qfrac) was linearly related to the relative change in Ctot (2005-2015; $\mathrm{r}^{2}=0.66, \mathrm{n}=60$; Fig. 11). This demonstrates the importance of the $C>20 \mu \mathrm{m}$ fraction not only as a sensitive indicator for the effect of changes in management practices, but that this ratio qfrac is a predictor of dynamics of topsoil SOC concentrations in these soils. Jaconi et al. (2019) demonstrated that a log ratio transformation of soil organic carbon fractions (in our case $\mathrm{C}>20 \mu \mathrm{m} / \mathrm{C}<20 \mu \mathrm{m}$ ) gave the best results for their prediction by VisNIR spectroscopy. Therefore, qfrac is suitable for future use in standard soil fertility analyses, which are likely to include spectroscopy as a routine analysis (Genot et al., 2011).

Comparable to changes in qfrac, changes in microbial quotient (i.e. qmic) have already been suggested as useful and sensitive indicators to predict long-term trends in SOM and for monitoring changes in SOC e.g. due to changes in management (Powlson et al., 1987). The changes in qmic reflect organic matter inputs to soils, the efficiency of conversion to microbial $\mathrm{C}$, losses of $\mathrm{C}$ from the soil and the stabilization of organic C by the soil mineral fractions (Anderson and Domsch, 1980, 1989; Wardle, 1992). Anderson and Domsch (1989) published an equilibrium 

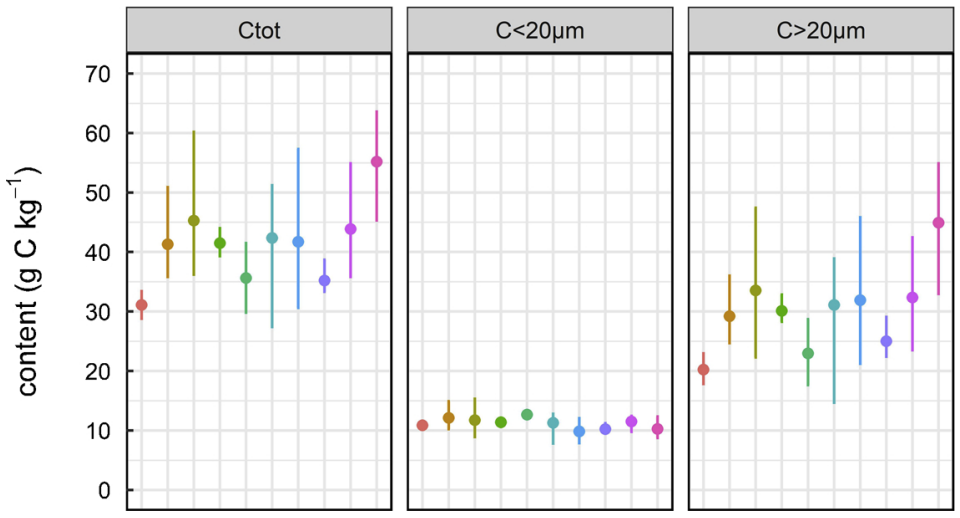

$\rightarrow$ Mt1

$\longrightarrow$ Mt2

$\longrightarrow \mathrm{Mp} 1$

$\multimap$ Mp5

$\rightarrow \mathrm{Mp} 2$

$\rightarrow \mathrm{Mp} 3$

$\rightarrow \mathrm{Mp} 4$

$\multimap \mathrm{Gp} 1$

$\multimap \mathrm{Gp} 2$

$\multimap \mathrm{Gp3}$
Fig. 10. Network of 49 grassland sites under agro-ecological schemes. Management intensity is decreasing from left to right along the $\mathrm{X}$ axis. See Table 1 for details on number of sites per treatment and management: $\mathrm{M}=$ mowing, $\mathrm{G}=$ grazing, $\mathrm{p}=$ permanent, $t$ is temporary. The error bars represent the minimum and maximum values. constant for qmic of 29 [mg MBC $\times \mathrm{g} \mathrm{Corg}^{-1}$ ] for continuous crop rotations and of 23 [MBC $\times \mathrm{g} \mathrm{Corg}^{-1}$ ] for monocultures. This equilibrium constant was valid for soils from the temperate climate zone of central Europe. Any deviation of the qmic from this equilibrium for any given soil would indicate that its C-content is increasing or decreasing. Insam et al. (1989) expanded this constant to an equilibrium function, which accounts for the influence of macroclimatic conditions by analyzing soils from 15 long-term sites from different climatic regions in the United States and Canada. The qmic showed a consistent trend depending on climate, as assessed by a precipitation/evaporation quotient (Insam et al., 1989). However, the relationship proposed by Insam et al. (1989), relating the qmic to a precipitation/evaporation quotient, generally underestimated the MBC contents of New Zealand soils, demonstrating that clay content and mineralogy also affect the qmic. It has to be tested if qfrac remains useful in soils from different climatic regions as an indicator for sites that restore/loose C.

\section{Conclusion}

Shaking a soil-water mixture and sieving at $20 \mu \mathrm{m}$ enables separating organic matter in a fine $(<20 \mu \mathrm{m})$ and a coarse $(>20 \mu \mathrm{m})$ fraction. The $\mathrm{C}$ concentrations in these fractions are related to biological indicators, such as microbial biomass $\mathrm{N}$ and $\mathrm{C}$ and potential respiration, and management effects, such as $\mathrm{C}$ input from farmyard manure, and land use, as well as relationships with regional environmental covariates, such as, precipitation and - for the fine fraction - flow length. Long-term trials and paired plots revealed that the coarse fraction is more sensitive than the fine fraction to changes in management and that the former already responds within $\sim 5$ years to changes in management. A different long-term behavior is observed between land-uses: i) in croplands, the fine fraction increases if the ratio of the coarse fraction to the Ctot $>0.5$, ii) in grasslands, the fine fraction at the surface does not react to changes in intensity of grazing and mowing or use of fertilizer, but the coarse fraction reacts quickly. The relatively stable $\mathrm{C}<20 \mu \mathrm{m}$ content in grassland surface soils with high biomass $\mathrm{C}$ input is in agreement with the $\mathrm{C}$ saturation concept. After all, earlier

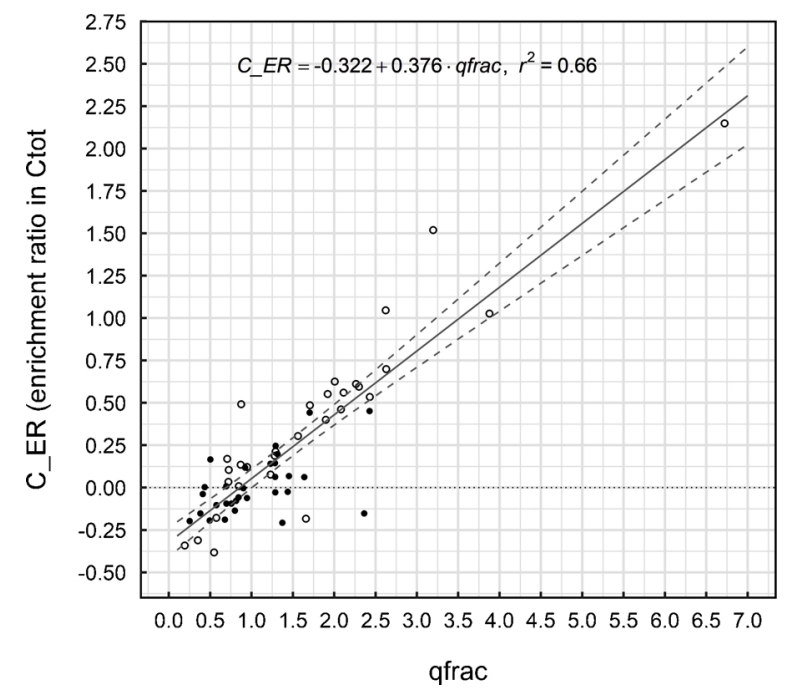

Fig. 11. The ratio $\mathrm{C}>20 \mu \mathrm{m} / \mathrm{C}<20 \mu \mathrm{m}$ (qfrac) against enrichment ratio in Ctot (C_ER: $\left(\right.$ Ctot $\left.\left._{2015}-\mathrm{Ctot}_{2005}\right) / \mathrm{Ctot}_{2005}\right)$ ) for cropland $(0-20 \mathrm{~cm}$; closed symbols) and grassland (0-10 cm; open symbols) sites in the Carbosol network sampled in 2005 and 2014-2016. The dashed lines are the 95\% confidence limits of the regression.

studies used grassland soils as the $\mathrm{C}$ saturation potential at a given fine silt and clay content. The coarse fraction is crucial for maintenance/ restoration of SOC because it: i) is the most reactive fraction from the biological point of view and in the longer term feeds the fine $\mathrm{C}$ fraction resulting in stable SOC stocks; and ii): reflects the integrated effect of agricultural management over ca. 10 years or more. For soils with reduced or no-till, care should be taken to sample deep enough to represent the former plough layer. Although the behavior of the indicators from the simple fractionation protocol is comparable to indicators based on soil microbial biomass, extrapolation to other climate and soil conditions as well as other sampling depths has not yet

Table 4

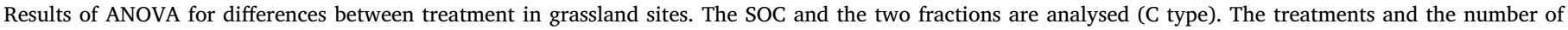
samples are explained in Sections 2.3 and 2.6.

\begin{tabular}{|c|c|c|c|c|c|}
\hline differences & Sites/Trials & test & C type & $\mathrm{p}$ & $\mathrm{df}$ \\
\hline \multirow[t]{3}{*}{ Grassland fertilization } & Libramont & ANOVA by permutation & Ctot & $<0.01$ & 3 \\
\hline & 4 treatments with 2 replicates & treatment as between-subjects factor & $\mathrm{C}<20 \mu \mathrm{m}$ & 0.19 & 3 \\
\hline & 4 samples per replicate & & $C>20 \mu \mathrm{m}$ & $<0.01$ & 3 \\
\hline \multirow[t]{3}{*}{ Grassland management } & BioEcoSys & ANOVA by permutation & Ctot & $<0.01$ & 9 \\
\hline & 10 treatments in Ardenne & treatment as between-subjects factor & $\mathrm{C}<20 \mu \mathrm{m}$ & 0.14 & 9 \\
\hline & 3 (4)replicates & & $C>20 \mu \mathrm{m}$ & $<0.01$ & 9 \\
\hline
\end{tabular}


been tested. The same applies to the energy levels for the fractionation. Sonication has a greater capacity to break up aggregates and hence increases the fine fraction. As the sensitivity of the fractions to changes in management is of prime importance, the energy required to separate a fraction that responds to management changes probably varies according to environmental conditions, so that we recommend testing and validation of this protocol for other soils and management regimes.

\section{Declaration of interests}

None.

\section{Acknowledgements}

This research was funded by the Public Administration of Wallonia (SPW-DGO3). The authors would like to thank Tabea Bartelt (TUM), Marco Bravin (UCLouvain), A. Degueldre (ULiège), A. Piret (ULiège) and M.-C. Requier (ULiège) for technical support. We acknowledge funding from the Bonares programme of the German Federal Ministry of Education and Research for Martin Wiesmeier (BonaRes Centre for Soil Research, FKZ 031A608C) and Eleanor Hobley (Soil3, FKZ 031B0026B). The Bioecosys project was funded by Moerman funds of the Belgian Federal Administration.

\section{References}

Allison, S.D., Wallenstein, M.D., Bradford, M.A., 2010. Soil-carbon response to warming dependent on microbial physiology. Nat. Geosci. 3, 336-340.

Anderson, J.P.E., Domsch, K.H., 1980. Quantities of plant nutrients in the microbial biomass of selected soils. Soil Sci. 130, 211-216.

Anderson, T.-H., Domsch, K.H., 1989. Ratios of microbial biomass carbon to total organic carbon in arable soils. Soil Biol. Biochem. 21, 471-479.

Anderson, T.-H., Domsch, K.H., 1993. The metabolic quotient for $\mathrm{CO}_{2}\left(q \mathrm{CO}_{2}\right)$ as a specific activity parameter to assess the effects of environmental conditions, such as $\mathrm{pH}$ the microbial biomass of forest soils. Soil Biol. Biochem. 25, 393-395.

Angers, D.A., Arrouays, D., Saby, N.P.A., Walter, C., 2011. Estimating and mapping the carbon saturation deficit of French agricultural topsoils. Soil Use Manage. 27, $448-452$.

Balesdent, J., 1996. The significance of organic separates to carbon dynamics and its modelling in some cultivated soils. Eur. J. Soil Sci. 47, 485-493.

Bimüller, C., Mueller, C.W., von Lützow, M., Kreyling, O., Koelbl, A., Haug, Stephan, Schloter, M., Kögel-Knabner, I., 2014. Decoupled carbon and nitrogen mineralization in soil particle size fractions of a forest topsoil. Soil Biol. Biochem. 78, 263-273.

Boulvain, F., Pingot, J.L., 2013. Genèse du sous-sol de la Wallonie. Académie Royale de la Belgique, Bruxelles.

Buysse, P., Roisin, C., Aubinet, M., 2013. Fifty years of contrasted residue management of an agricultural crop: impacts on the soil carbon budget and on soil heterotrophic respiration. Agric. Ecosyst. Environ. 167, 52-59.

Chartin, C., Stevens, A., Goidts, E., Krüger, I., Carnol, M., van Wesemael, B., 2017. Mapping Soil Organic Carbon stocks and estimating uncertainties at the regional scale following a legacy sampling strategy (Southern Belgium, Wallonia). Geoderma Reg. 9, 73-86.

Craine, J.M., Morrow, C., Fierer, N., 2007. Microbial nitrogen limitation increases decomposition. Ecology 88, 2105-2113.

Dendoncker, N., van Wesemael, B., Rounsevell, M., Roelandt, C., 2004. Belgium's $\mathrm{CO}_{2}$ mitigation potential under improved cropland management. Agric. Ecosyst. Environ. 103, 101-116.

Feng, W., Plante, A.F., Six, J., 2013. Improving estimates of maximal organic carbon stabilization by fine soil particles. Biogeochemistry 112, 81-93.

Fontaine, S., Bardoux, G., Abbadie, L., Mariotti, A., 2004. Carbon input to soil may decrease soil carbon content. Ecol. Lett. 7, 314-320.

Genot, V., Colinet, G., Bock, L., Vanvyve, D., Reusen, Y., Dardenne, P., 2011. Near infrared reflectance spectroscopy for estimating soil characteristics valuable in the diagnosis of soil fertility. J. Near Infrared Spectrosc. 19, 117-138.

Goidts, E., van Wesemael, B., 2007. Regional assessment of soil organic carbon changes under agriculture in Southern Belgium (1955-2005). Geoderma 141, 341-354.

Goidts, E., Van Wesemael, B., Van Oost, K., 2009. Driving forces of soil organic carbon evolution at the landscape and regional scale using data from a stratified soil mon itoring. Glob. Chang. Biol. 15, 2981-3000.

Hart, S.C., Strak, J.M., Davidson, E.A., Firestone, M.K., et al., 1994. Nitrogen mineralization, immobilization, and nitrification. In: Weaver, R.W. (Ed.), Methods of Soil Analysis: Part 2-Microbiological and Biochemical Properties. Soil Science Society of America, pp. 985-1018.

Hassink, J., 1997. The capacity of soils to preserve organic C and N by their association with clay and silt particles. Plant Soil 191, 77-87.

Hobley, E.U., Wilson, B., 2016. The depth distribution of organic carbon in the soils of eastern Australia. Ecosphere 7, e1214.

Hobley, E., Willgoose, G.R., Frisia, S., Jacobsen, G., 2013. Environmental and site factors controlling the vertical distribution and radiocarbon ages of organic carbon in a sandy soil. Biol. Fertil. Soils 49, 1015-1026.
Hobley, E., Wilson, B., Wilkie, A., Gray, J., Koen, T., 2015. Drivers of soil organic carbon storage and vertical distribution in Eastern Australia. Plant Soil 390, 111-127.

Hobley, E.U., Baldock, J., Wilson, B., 2016. Environmental and human influences on organic carbon fractions down the soil profile. Agric. Ecosyst. Environ. 223, 152-166.

Insam, H., Parkinson, D., Domsch, K.H., 1989. Influence of macroclimate on soil microbial biomass. Soil Biol. Biochem. 21, 211-221.

IUSS Working Group WRB, 2015. World Reference Base for Soil Resources 2014. update 2015.

Jaconi, A., Poeplau, C., Ramirez Lopez, L., van Wesemael, B., Don, A., 2019. Log-ratio transformation is the key to determining soil organic carbon fractions with nearinfrared spectroscopy. Eur. J. Soil Sci (in press).

Jenkinson, D.S., Brookes, P.C., Powlson, D.S., 2004. Measuring soil microbial biomass. Soil Biol. Biochem. 36 (1), 5-7.

Jenness, J., 2006. Topographic Position Index (tpi jen. avx) Extension for ArcView 3. x, v. 1.3 a. Jenness Enterprises.

Joergensen, R.G., Mueller, T., 1996. The fumigation-extraction method to estimate soil microbial biomass: calibration of the kEN value. Soil Biol. Biochem. 28, 33-37.

Jonard, F., Mahmoudzadeh, M., Roisin, C., Weihermüller, L., André, F., Minet, J., Vereecken, H., Lambot, S., 2013. Characterization of tillage effects on the spatial variation of soil properties using ground-penetrating radar and electromagnetic induction. Geoderma 207-208, 310-322.

Kemmitt, S.J., Lanyon, C.V., Waite, I.S., Wen, Q., Addiscott, T.M., Bird, N.R.A., O’Donnell, A.G., Brookes, P.C., 2008. Mineralization of native soil organic matter is not regulated by the size, activity or composition of the soil microbial biomass-a new perspective. Soil Biol. Biochem. 40, 61-73.

Kibblewhite, M.G., Chambers, B.J., Goulding, K.W.T., 2016. How good is the evidence to support investment in soil protection? Soil Use Manag. 32, 172-182.

Kirkby, C.A., Richardson, A.E., Wade, L.J., Passioura, J.B., Batten, G.D., Blanchard, C. Kirkegaard, J.A., 2014. Nutrient availability limits carbon sequestration in arable soils. Soil Biol. Biochem. 68, 402-409.

Krüger, I., Chartin, C., van Wesemael, B., Carnol, M., 2018. Reference systems of biological indicators and assessment of soil quality: implications of scale, spatial and temporal variability. Ecol. Indic. 95, 568-578.

Lal, R., 2016. Soil health and carbon management. Food Energy Secur. 5, 2012-2022.

Leifeld, J., Kögel-Knabner, I., 2005. Soil organic matter fractions as early indicators for carbon stock changes under different land-use? Geoderma 124, 143-155.

Liang, C., Schimel, J.P., Jastrow, J.D., 2017. The importance of anabolism in microbial control over soil carbon storage. Nat. Microbiol. 2 (8) art. no. 17105

Meersmans, J., De Ridder, F., Canters, F., De Baets, S., Van Molle, M., 2008. A multiple regression approach to assess the spatial distribution of Soil Organic Carbon (SOC) at the regional scale (Flanders, Belgium). Geoderma 143, 1-13.

Meersmans, J., Van Weverberg, K., De Baets, S., De Ridder, F., Palmer, S.J., van Wesemael, B., Quine, T.A., 2016. Mapping mean total annual precipitation in Belgium, by investigating the scale of topographic control at the regional scale. J. Hydrol. (Amst) 540, 96-105.

Minasny, B., McBratney, A.B., 2006. A conditioned Latin hypercube method for sampling in the presence of ancillary information. Comput. Geosci. 32, 1378-1388.

Minasny, B., Malone, B.P., McBratney, A.B., Angers, D.A., Arrouays, D., Chambers, A., Chaplot, V., Chen, Z.-S., Cheng, K., Das, B.S., Field, D.J., Gimona, A., Hedley, C.B., Hong, S.Y., Mandal, B., Marchant, B.P., Martin, M., McConkey, B.G., Mulder, V.L., O'Rourke, S., Richer-de-Forges, A.C., Odeh, I., Padarian, J., Paustian, K., Pan, G., Poggio, L., Savin, I., Stolbovoy, V., Stockmann, U., Sulaeman, Y., Tsui, C.-C.,

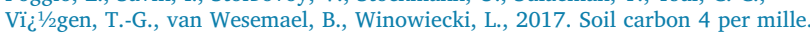
Geoderma 292, 59-86.

Poeplau, C., Don, A., 2014. Effect of ultrasonic power on soil organic carbon fractions. J. Plant Nutr. Soil Sci. 177, 137-140.

Poeplau, C., Don, A., Six, J., Kaiser, M., Nieder, R., Benbi, R., Chenu, C., Cotrufo, F., Derrien, D., Grand, S., Gregorich, E., Griepentrog, M., Gunina, M., Kuzyakov, Y., Kühnel, A., MacDonald, L., Nebbioso, A., Soong, J., Trigalet, S., Vermeire, M.L., Rovira, P., van Wesemael, B., Wiesmeier, M., Yeasmin, S., 2018. Isolating soil organic carbon fractions with varying turnover times- A comprehensive comparison of fractionation methods. Soil Biol. Biochem. 125, 10-26.

Powlson, D.S., Brookes, P.C., Christensen, B.T., 1987. Measurement of soil microbial biomass provides an early indication of changes in total soil organic matter due to straw incorporation. Soil Biol. Biochem. 19, 159-164.

Renard, K.G., Foster, G.R., Weesies, G.A., Porter, J.P., 1991. RUSLE: revised universal soil loss equation. J. Soil Water Conserv. 46, 30-33.

Rutgers, M., Schouten, A.J., Bloem, J., van Eekeren, N., de Goede, R.G.M., Jagersop Akkerhuis, G.A.G.M., Vander Wal, A., Mulder, C., Brussaard, L., Breure, A.M., 2009. Biological measurements in a nationwide soil monitoring network. Eur. J. Soil Sci. $60,820-832$.

Sherrod, L.A., Dunn, G., Peterson, G.A., Kolberg, R.L., 2002. Inorganic carbon analysis by modified pressure-calcimeter method. Soil Sci. Soc. Am. J. 66 (1), 299-305.

Six, J., Conant, R.T., Paul, E.A., Paustian, K., 2002. Stabilization mechanisms of soil organic matter: implications for C-saturation of soils. Plant Soil 241, 155-176.

Stewart, C.C., Plante, A.F., Paustian, K., Conant, R.T., Six, J., 2008. Soil carbon saturation: linking concept and measurable pools. Soil Sci. Soc. Am. J. 72, 379-392.

Strobl, C., Boulesteix, A., Zeileis, A., Hothorn, T., 2007. Bias in random forest variable importance measures: illustrations, sources and a solution. BMC Bioinf. 8, 25.

Tisdall, J.M., Oades, J.M., 1982. Organic matter and water-stable aggregates in soils. J. Soil Sci. 33, 141-163.

Totsche, K.U., Amelung, W., Gerzabeck, M.H., Guggenberger, G., Klumpp, E., Kniel, C., Lehndorff, E., Mikutta, R., Peth, S., Prechtel, A., Ray, N., Kögel-Knabner, I., 2018. Microaggregates in soil. J. Plant Nutr. Soil Sci. (1999) 181, 104-136.

Trigalet, S., Van Oost, K., Roisin, C., van Wesemael, B., 2014. Carbon associated with clay and fine silt as an indicator for SOC decadal evolution under different residue management practices. Agric. Ecosyst. Environ. 196, 1-9.

Trigalet, S., Gabarrón-Galeote, M.A., Van Oost, K., van Wesemael, B., 2016. Changes in soil organic carbon pools along a chronosequence of land abandonment in southern Spain. Geoderma 268, 14-21. 
van Wesemael, B., Paustian, K., Meersmans, J., Goidts, E., Barancikova, G., Easter, M., 2010. Agricultural management explains historic changes in regional soil carbon stocks. PNAS 107, 14926-14930.

Vance, E.D., Brookes, P.C., Jenkinson, D.S., 1987. Microbial biomass measurements in forest soils: the use of the chloroform fumigation-incubation method in strongly acid soils. Soil Biol. Biochem. 19 (6), 697-702.

Von Lützow, M., Kögel-Knabner, I., Ekschmitt, K., Flessa, H., Guggenberger, G., Matzner, E., Marschner, B., 2007. SOM fractionation methods: relevance to functional pools and to stabilization mechanisms. Soil Biol. Biochem. 39, 2183-2207.

Wardle, D.A., 1992. A comparative assessment of factors which influence microbial biomass carbon and nitrogen levels in soil. Biol. Rev. 67, 321-358.

Wiesmeier, M., Hübner, R., Spörlein, P., Geuß, U., Hangen, E., Reischl, A., Schilling, B., von Lützow, M., Kögel-Knabner, I., 2014. Carbon sequestration potential of soils in southeast Germany derived from stable soil organic carbon saturation. Glob. Chang. Biol. 20, 653-665.

Zar, J.H., 1999. Biostatistical Analysis. Prentice Hall, New Jersey. 